\title{
ENKULTURISASI DALAM KEBUDAYAAN MELAYU
}

\author{
Husni Thamrin \\ E-mail : husnithamrin023@gmail.com \\ Postgraduated Program of UIN Sultan Syarif Kasim Riau
}

\begin{abstract}
This paper spreads the enculturation of Malay culture that has universal values which are recognized by human beings, such as the value of belief in the power of the Creator, God, the value of "same inner" in beings, the value of deliberation and consensus, as well as keeping and creating justice. So that the Malays have dignity which is seen aligned with other human beings and society. There are several fundamental values that the Malays are very firmly keep their customs. Malay custom consists of three categories: (1) The real indigenous customs derived from God (Quran and Sunnah); (2) The indigenous customs from the reins holderof power, king or sultan; (3) The indigenous customs from the agreement of the community leader which is adhered by the next generations as long as still in tune with the ongoing-development. Enculturation of Malay culture has a lot of contact with Islamic values. It gives conducive, elegant, and universal patterns to the Malay culture.
\end{abstract}

Keywords: Enculturation, customary, Islam and Malay.

\section{PENDAHULUAN}

Orang Melayu lebih mengutamakan budi, karena budi itu terkait dengan bahasa. Raja Ali Haji dalam Gurindam Duabelas menyatakan "budi bahasa menentukan bangsa". Laporan tentang orang Melayu oleh Tomes Pires dari Portugis menguraikan tentang kebiasaan, undang-undang, dan perdagangan Malaka terkemuka, muslim yang taat, kehidupan yang menyenangkan dan memiliki karakternya; halus budi bahasanya, sopan, gemar musik, dan cenderung saling menyayangi (Alatas, 1988: 48-49).

Ciri Melayu sejak orang Melayu menganut Islam dikenal ialah beradat dan berbahasa Melayu. Adat Melayu menganut filosofi: "Adat bersendi syarak, syarak bersendi Kitabullah, syarak mengatakan, adat memakai".

Faktor-faktor kelebihan pihak lain itu perlu dianalisis secara mendalam. Kendala-kendala yang dialami untuk majunya masyarakat Melayu bahwa adanya faktor-faktor: psikologis, cenderung apologis, dan kurang rasional. Kendala yang bersifat struktural merupakan kendala yang berkorelasi pula dengan hambatan kultural yang telah mengikat secara inheren dalam diri orang Melayu. Faktor lain dikatakan Samin (2003: 53) penafsiran agama yang keliru bahwa hidup tergantung kepada nasib, kurang menghargai profesi pedagang dan ilmu pengetahuan, merupakan faktor kunci ketertinggalan orang Melayu masa kini.

Harapan ke depan perlu dikembangkan supaya budaya Melayu dan Islam yang berkultur bahari (maritime-based) itu mampu memberikan 
achievement motivation kepada generasi kini, supaya generasi ke depan dapat meraih kegemilangan. Tidak kalah penting bahwa konsep, filosofi kebudayaan Melayu dan nilai-nilai Islam harus mampu mempertemukan, untuk membentuk orang Melayu mempunyai wujud ukhuwah (need for affiliation) dan quwwah (need for achievement). Realitas sosial perlu dikembalikan kepada usaha-usaha supaya kebudayaan Melayu dan Islam dijadikan dasar, payung, dan mahkota masyarakatnya.

\section{ADAT ISTIADAT DALAM MASYARAKAT MELAYU}

Adat bagi masyarakat Melayu, khususnya Melayu Riau, memegang peran yang sangat sentral dalam kehidupan bermasyarakat. Adat sebagai salah satu sistem nilai, sepanjang sejarah keberadaannya telah mengalami berbagai bentuk akibat dari perubahan keyakinan yang dianut masyarakat di daerah ini. Namun semenjak, Islam masuk ke daerah ini, adat yang bersumber dari Islam diakui sebagai yang paling asasi dan merupakan rujukan dari sistem nilai lainnya. Sistem nilai ini berjalan dan dipatuhi masyarakat bukan karena adanya suatu lembaga atau badan tertentu sebagai pengontrol tetapi lebih didasarkan kepada kesadaran dan kepatuhan masyarakat terhadap perintah agamanya. Hal ini tercermin dalam pepatah adat yang mengatakan 'adat bersendi syara', syara' bersendi kitabulllah, syara' mengata adat memakai, ya kata syara', benar kata adat, adat tumbuh dari syara', syara' tumbuh dari kitabullah". Itu artinya, semua aspek budaya dan norma sosial masyarakat Siak wajib merujuk kepada ajaran Islam dan dilarang bertikai apalagi menyalahinya. Sebaliknya nilai budaya yang dianggap belum serasi dan belum sesuai dengan ajaran Islam haruslah "diluruskan" dan disesuaikan dengan Islam, Acuan ini menyebabkan Islam tidak dapat dipisahkan dari adat maupun norma-norma sosial lainnya dalam kehidupan orang Melayu-Siak. Tidak hanya sampai disitu, bahkan Islam sudah diidentifikasi dengan Melayu. Orang Cina yang masuk Islam tidak disebut "masuk Islam", akan tetapi "masuk Melayu". Sebaliknya, bila orang Melayu keluar dari Islam, maka tanggallah hak dan kewajibannya sebagai orang Melayu. Dalam ungkapan adat dikatakan "siapa meninggalkan syara', maka ia meninggalkan Melayu. Siapa memakai syara', maka ia masuk Melayu". Dalam ungkapan lain dikatakan, "bila tanggal syara", maka gugurlah Melayu-nya".

Dengan demikian, jelas bahwa sebagaimana halnya masyarakat yang agamis, tata kehidupan dan hubungan kemasyarakatan, masyarakat melayu, khususnya Melayu-Siak berpegang teguh pada al-Qur'an dan al-Hadis di samping hukum yang tidak tertulis yang disebut dengan hukum adat. Kedua sistem hukum tersebut merupakan hukum yang hidup dalam kehidupan dan perilaku masyarakat Melayu di daerah ini. 
Sampai saat ini polemik antara ahli hukum tentang problem hubungan hukum Islam dan hukum adat masih belum selesai. Pada awalnya Van Der Ber menyatakan bahwa yang berlaku untuk orang Islam di Indonesia adalah hukum Islam. Ahli hukum lainnya, seperti C. Van Vollenhoven dan C. Snouck Hurgronje menyatakan yang sebaliknya, bahwa yang berlaku di Indonesia adalah hukum adat. Hukum Islam baru berlaku jika bisa diterima oleh hukum adat. Sementara Hazairin mengatakan, bahwa berlakunya hukum Islam di Indonesia tidak berdasarkan hukum adat. Sebaliknya hukum adat baru bisa berlaku jika tidak bertentangan dengan hukum Islam. Artinya, jika terjadi sengketa antara orang Islam, maka penyelesaiannya dilakukan dengan berpedoman kepada al-Quran dan Hadis atau kepada hukum adat jika tidak bertentangan dengan al-Qur'an maupun al-Hadis.

Dalam Undang-Undang Nomor 7 tahun 1989 tentang Peradilan Agama dan Inpres Nomor 1 tahun 1991 tentang Kompilasi Hukum Islam, justru tidak memuat keharusan terhadap setiap sengketa antara orang Islam, khususnya kewarisan, diselesaikan di Pengadilan Agama. Bahkan, dalam Surat Edaran Mahkamah Agung (SEMA) Nomor 2 tahun 1990 memberikan hak opsi terhadap pihak-pihak yang bersengketa. Ada tiga aturan hukum yang dapat dipedomani dalam pelaksanaan kewarisan, yakni hukum Islam, hukum adat, dan hukum perdata (BW). Surat Edaran Mahkamah Agung (SEMA) Nomor 2 tahun 1990 berbunyi;"Perkara-perkara antara orang-orang yang beragama Islam di bidang kewarisan juga berkaitan dengan masalah pilihan hukum. Hendaknya diketahui bahwa ketentuan pilihan hukum merupakan masalah yang terletak di luar badan peradilan dan berlaku bagi mereka atau golongan rakyat yang hukum warisnya tunduk pada hukum adat atau tunduk pada hukum perdata Barat (BW) dan atau hukum Islam dimana mereka boleh memilih hukum adat atau hukum perdata Barat (BW) yang menjadi wewenang Pengadilan Negeri, atau memilih hukum Islam yang menjadi wewenang pengadilan Agama". ${ }^{1}$

Di sisi lain, banyak pakar terutama dari kalangan orientalis yang memberikan komentar negatif berkaitan dengan integrasi antara dua sistem hukum tersebut dengan mengatakan, bahwa Islam di daerah ini sebagai "Islam periferal", Islam pinggiran, Islam yang jauh dari bentuk "asli" yang terdapat dan berkembang di Timur Tengah. Artinya, Islam di daerah ini bukan "Islam yang sebenarnya", seperti Islam yang berkembang dan terdapat di tempat asal mulannya muncul. Pendapat tersebut, misalnya dikemukakan oleh K.P. London, Winstedt, dan van Leur. Van Leur lebih lanjut mengatakan, bahwa Islam di daerah Indo-Melayu merupakan lapisan tipis yang mudah mengelupas dalam timbunan budaya setempat. Islam tidak membawa

1 Lihat SEMA No. 2 Tahun 1980, 
pembaruan sepotongpun ke tingkat perkembangan yang lebih tinggi, baik secara sosial, ekonomi, maupun pada tataran negara atau perdagangan. ${ }^{2}$

Teori Receptio in Complexu yang dikemukakan oleh Van Den Berg (1845127) yang mengatakan, bahwa yang berlaku untuk orang Islam di Indonesia adalah hukum Islam. Hal ini didasarkan pada pada pasal 75 RR (stbl. Hindia Belanda tahun 1955).Teori Receptio yang dikemukakan oleh C. Van Vollenhoven (1874-1933) dan C. Snouck Hurgronje (1857-1936). Mereka mengatakan bahwa yang berlaku di Indonesia adalah adat asli. Hukum Islam baru berlaku jika bisa diterima (diresepsi) oleh hukum adat. Hal yang sama dikemukakan oleh W. Marcais, seorang orientalis berkebangsaan Perancis, yang menggagas Teori Pelapisan (Superimposition Theory).

Pada dasarnya teori ini menjelaskan bahwa fardh (fixed shares) hukum Islam diambil dari praktik-praktik waris pra Islam. Al-Qur’an yang menetapkan hak-hak waris antara suami-isteri dan para kerabat dekat perempuan dengan memberikan fardh warisan kepada mereka. Aturanaturan itu dengan sendirinya bukan merupakan suatu sistem yang komplit, tetapi hanya modifikasi dari golongan ahli waris di atasnya. 'Ashabah, para ahli waris pra Islam, masih mewarisi tetapi sekarang hanya setelah warisan itu dibagikan kepada ahli waris yang ditetapkan Al-Qur'an (ahl al-faraidh). Dua elemen heterogen itu, hukum adat tribal Arabia pra Islam dan legislasi alQur'an, kemudian dilebur menjadi satu membentuk "ilmu al-faraidh".

Teori ini didukung oleh hampir seluruh orientalis dan kebanyakan ahli sejarah. Mereka hanya melihat legislasi hukum waris al-Qur'an sebagai reformasi adhoc yang dirancang untuk melengkapi hukum adat tribal Arabia di zaman pra Islam. David S.Powers mengatakan, bahwa al-Qur'an memperkenalkan sistem pewarisan yang lengkap yang mengandung ketentuan untuk pewarisan ab intestato dan testamentair yang menggantikan sepenuhnya hukum adat tribal Arabia pra islam. Akan tetapi, memang tidak identik dengan apa yang saat ini dikenal dengan hukum kewarisan islam. Sebab, sesudah wafatnya Nabi Muhammad SAW terdapat orang-orang tertentu yang telah memanifulasi teks al-Qur'an dalam upaya mengubah makna ayat-ayat yang terkait dengan waris, sementara masyarakat muslim dewasa ini tidak memiliki pembacaan dan pemahaman yang tepat atas ayat-ayat al-Qur an dan hadis dimaksud atau atas sistem waris yang diterima oleh Muhammad. ${ }^{3}$ Teori Receptio a Contrario yang digagas oleh Hazairin yang mengatakan, bahwa berlakunya hukum Islam di Indonesia tidak

2 J.C van Leur, Indonesian Trade and Society, (Den Haag: van Hoeve, 1955), hlm 169

3 David S.Powers, Peralihan Kekayaan dan Politik Kekuasaan: Kritik Historis Hukum Waris, terj. Arif Maftuhin, (Yogyakarta: LkiS, 2001), cet I, hlm. ix. 
berdasarkan hukum adat, tetapi didasarkan pada penunjukan peraturan dan perundang-undangan tersendiri. Dengan demikian hukum adat baru bisa berlaku jika tidak bertentangan dengan hukum Islam.

Abdullah Syah mengatakan, bahwa integrasi antara adat Temenggong dengan hukum kewarisan Islam di Kecamatan Tanjung Pura Langkat berlangsung dengan cara pengadopsian kewarisan hukum adat dengan memberinya label Islam. Hal ini dimungkinkan karena adanya kesamaan antara kedua sistem hukum tersebut. ${ }^{4}$ Amir Syarifuddin dalam karyanya yang berjudul, "Pelaksanaan Hukum Kewarisan Islam dalam Lingkungan Adat Minangkabau", membagi interaksi kewarisan hukum adat dengan hukum kewarisan Islam kepada tiga macam, yaitu; pertama, adat dan syara' berjalan sendiri-sendiri dalam batas yang tidak saling mempengaruhi; kedua, adat dan syara' menuntut haknya masing-masing hingga keduanya diperlakukan sama tanpa menggeser kedudukan yang lain, bahkan dalam pelaksanaannya salah satu di antaranya menyandar pada pihak lain; ketiga, tahap kompromi dan penyesuaian antara hukum adat dan Islam. ${ }^{5}$

Studi dalam bentuk kajian hukum normatif/doktriner, misalnya penelitian yang dilakukan Hajar M. dari Universitas Islam Indonesia (UII) Yogyakarta tahun 2002. Penelitian dalam bentuk thesis dengan judul "Perkembangan Hukum Islam di Indonesia: Studi atas Keberadaan Hukum Kewarisan", peneliti menyimpulkan bahwa keberadaan hukum kewarisan Islam di Indonesia pada masa pemerintahan kolonial Belanda merupakan hukum yang hidup dan ditaati oleh masyarakat Islam. Hukum itu secara bertahap mulai eksis sejalan dengan diterimanya Islam sebagai agama, dan setelah berdirinya kerajaan-kerajaan Islam, hukum tersebut merupakan satusatunya sistem hukum yang dijalankan dan menjadi kesadaran hukum bagi mayoritas masyarakat Indonesia. Kebijakan-kebijakan yang dibuat oleh pemerintah kolonial yang bertujuan untuk menghapus hukum kewarisan Islam dan menggantinya dengan hukum kewarisan yang berlaku di negaranya, tidak pernah berhasil. Bahkan, keberadaan hukum kewarisan Islam secara "terpaksa" dimasukkan ke alam peraturan perundangundangan. Meskipun, keberadaan hukum kewarisan Islam tersebut pada akhirnya dihapus, namun hukum tersebut tetap eksis dan dipatuhi oleh masyarakat. ${ }^{6}$

4 Abdullah Syah, Integrasi Antara Hukum Islam dan Hukum Adat dalam Kewarisan Suku Melayu di Kecamatan Tanjung Pura Langkat, (Jakarta: PPs IAIN Syarif Hidayatullah, 1986), hlm. 358-365.

5 Amir Syarifuddin, Pelaksanaan Hukum Kewarisan Islam dalam Lingkungan Adat Minangkabau, (Jakarta: Gunung Agung, 1984), hlm. 189-179. 
Selanjunya peneliti mengatakan, bahwa keberadaan hukum kewarisan Islam di Indonesia setelah kemerdekaan tetap diakui dan menjadi kesadaran hukum masyarakat (lifing law). Meskipun bagi wilayah Jawa, Madura, dan sebagian Kalimantan Selatan dan Timur masih berlaku pasal 134 ayat 2 IS peninggalan pemerintahan kolonial yang mencabut hukum kewarisan Islam, namun hukum tersebut tetap dipakai untuk menyelesaikan perkara kewarisan oleh masyarakat. Bagi wilayah luar Jawa, Madura, dan sebagian Kalimantan Selatan dan Timur, politik hukum Hindia Belanda yang mencabut hukum kewarisan Islam tidak berlaku. Oleh sebab itu, keberadaan hukum kewarisan Islam tetap berlaku baik dalam tatanan masyarakat maupun dalam peraturan perundang-undangan. Dengan keluarnya PP No. 45 tahun 1957, keberadaan hukum kewarisan Islam bagi wilayah tersebut mendapat legitimasi dari pemerintah. Kesan, bahwa pasal 134 ayat 2 IS sebagai sumber formal dari teori Resepsi yang terdapat dalam PP tersebut tidak mempengaruhi keberadaan hukum kewarisan Islam dalam tatanan masyarakat. ${ }^{7}$

Adapun Keberadaan hukum kewarisan Islam di Indonesia pasca tahun 1989 diperkuat dengan lahirnya UU No. 7 Tahun 1989 tentang Peradilan Agama. Hanya saja keberadaan hukum kewarisan Islam masih bersifat alternatif. Dengan adanya hak opsi, menunjukkan bahwa teori Resepsi melalui pasal 134 ayat 2 IS memiliki implikasi terhadap UU tersebut. Untuk menghindari hak opsi itu maka kalimat "yang dilakukan berdasarkan hukum Islam", yang terdapat dalam pasal 49 ayat 1 huruf b harus dihapus atau dihilangkan. ${ }^{8}$

Selanjutnya peneliti mengatakan, bahwa perkembangan hukum kewarisan Islam dalam $\mathrm{KHI}$ dapat dikategorikan menjadi dua, yaitu; perkembangan yang sejalan dengan kehendak atau prinsip nash, dan perkembangan yang harus mendapat perhatian untuk disempurnakan. Kategori pertama, terdapat dalam pasal 171 huruf (e), 183, 187, 189, 190, 209 , dan pasal 229. Pada kategori kedua adalah pasal 173, 177, 185, dan 211. Kedudukan hukum kewarisan Islam sebagai hukum positif dalam sistem hukum nasional masih terkesan dilematis. Di satu sisi ia tidak termasuk dalam tata urutan perundang-undangan sehingga diketegorikan sebagai hukum tidak tertulis. Di sisi lain ia merupakan law dan rule yang diangkat menjadi law dengan potensi political power. Lagi pula hukum kewarisan Islam

6 Hajar. M, Perkembangan Hukum Islam di Indonesia: Studi Atas Keberadaan Hukum Kewarisan, (Yogyakarta: Pascasarjana UII, 2002), hlm. 163.

7lbid, hlm. 164

8lbid. 
tersebut digali dari sumber hukum refresentatif dan merupakan aspirasi dari mayoritas masyarakat yang sesuai dengan kehendak Pancasila UUD 1945. Sebagai hukum tidak tertulis kedudukan hukum kewarisan islam dapat digambarkan dengan adanya koherensi antara sistem hukum anglo saxon dan sistem hukum continental dalam sistem hukum Indonesia. ${ }^{9}$

Penelitian lainnya adalah karya David S. Power dengan judul "Peralihan Kekayaan dan Politik kekuasaan: Kritik Historis Hukum Waris". Karya ini merupakan pengembangan disertasi beliau pada Princeton University tahun 1975, yang mengkaji teks-teks ayat al-Qur'an dan al-hadis yang menyangkut kewarisan melalui metode kritik terhadap sintaksis dan makna kata waris dengan menggunakan pendekatan linguistik dan leksikografig untuk kemudian membandingkannya dengan kasus kewarisan yang terjadi pada abad pertengahan di Spanyol dan di Afrika Utara.David S. Powers mengatakan, bahwa ketentuan-ketentuan kewarisan termasuk salah satu aspek yang secara canggih dan lengkap diatur dalam al-Qur'an, namun dalam kenyataannya terdapat perbedaan dengan praktik kewarisan yang berlaku pada masyarakat Islam, khususnya pada masyarakat Islam Spanyol dan Afrika Utara. Untuk mencari jawaban terhadap kesenjangan itu, David S. Powers menggunakan perangkat metodologi dan penyelidikan khas kalangan revisionis yang dilengkapi dengan studi historis yang ketat. Dengan alat-alat analisis dan literatur dalam sejumlah ayat waris al-Qur'an dan hadis, ia menelusuri pola dan sejarah penafsiran yang berujung pada pendapat bahwa apa yang disebut hukum waris Islam tidak identik dengan sistem waris yang diwahyukan kepada Nabi Muhammad. ${ }^{10}$

Dalam karya ini, David S. Powers juga menjelaskan tentang teori "pelapisan" (superimposition theory) yang dikemukakan oleh orientalis Perancis yang bernama W. Marcais. Teori ini merupakan pengembangan dari pendapat W. Roberton Smith dalam karyanya yang berjudul "Khinsip and Marriage in Early Arabic". Teori pelapisan pada intinya menjelaskan bahwa fardh (fixed shares) hukum Islam diambil dari praktik-praktik waris pra Islam. Al-Qur'an menetapkan hak-hak waris antara suami-isteri dan para kerabat dekat perempuan dengan memberi fardh warisan kepada mereka. Aturanaturan itu dengan sendirinya bukan merupakan suatu sistem yang komplit, tetapi hanya modifikasi akan golongan ahli waris baru di atasnya. Ashabah, para ahli waris pra Islam masih mewarisi tetapi sekarang hanya setelah warisan itu dibagikan kepada para ahli waris yang ditetapkan al-Qur’an (ahl

9lbid

10 David S.Powers, Peralihan Kekayaan dan Politik Kekuasaan: Kritik Historis Hukum Waris, terj. Arif Maftuhin, (Yogyakarta: LkiS, 2001), cet. I, hlm. 256-265. 
al-faraidh). Dua elemen heterogen, yaitu; hukum adat tribal arabiah pra Islam dan legislasi al-Qur'an, kemudian dileburkan menjadi satu bentuk yang kemudian dinamakan IImu al-Faraidh. ${ }^{11}$ Menurut David S. Powers munculnya teori pelapisan yang didukung oleh hampir seluruh orientalis dan kebanyakan ahli sejarah, hanya melihat legislasi hukum waris al-Qur'an sebagai reformasi adhoc yang dirancang untuk melengkapi hukum adat tribal arabiah di zaman pra Islam. Selanjutnya dia mengatakan, bahwa al-Qur'an memperkenalkan sistem pewarisan yang lengkap yang mengandung ketentuan untuk pewarisan ab-intestato dan testamentair yang menggantikan sepenuhnya hukum adat waris tribal arabiah pra Islam. Akan tetapi, memang tidak identik dengan apa yang saat ini dikenal dengan hukum kewarisan Islam. Sebab, sesudah wafatnya Nabi Muhammad terdapat orang-orang tertentu yang telah memanifulasi teks al-Qur'an dalam upaya mengubah makna ayat-ayat yang terkait dengan waris, sementara masyarakat muslim dewasa ini tidak memiliki pembacaan dan pemahaman yang tepat atas ayat-ayat al-Qur'an dan hadis dimaksud atau atas sistem waris yang diterima oleh Muhammad. ${ }^{12}$ Pada masyarakat Minangkabau yang menganut Adat Perpatih, menurut Amir Syarifuddin, interaksi kedua sistem hukum tersebut dapat terjadi melalui tiga tahap. Pada tahap awal, adat dan syarak berjalan sendiri-sendiri dalam batas yang tidak salng mempengaruhi. Hal ini tergambar dalam pepatah, "adat bersendi alur dan patut, dan syarak bersendi dalil". Tahap kedua, salah satu pihak menuntut haknya pada pihak lain hingga keduanya diperlakukan sama tanpa menggeser kedudukan yang lain, bahkan dalam pelaksanaannya salah satu di antaranya menyandar pada pihak lain. Tahap kedua ini tergambar dalam pepatah "adat bersendi syarak, dan syarak bersendi adaf". Pada tahap ketiga, terjadi kompromi dan penyesuaian antara hukum Islam dan adat, sebagaimana tergambar dalam pepatah, "adat bersendi syarak, syarak bersendi kitabullah, syarak mengato, adat memakai". 13

Selanjutnya Amir Syarifuddin mengatakan, bahwa penundukan adat kepada Islam dalam tahap ini tidaklah berarti bahwa adat dengan sendirinya telah menyesuaikan diri sepenuhnya dengan Islam, karena penyesuaian ini memerlukan waktu yang cukup panjang dan tidak terjadi tanpa benturan.

11/bid, hal. 21.

12Ibid, hlm. ix.

13 Amir Syarifuddin, Pelaksanaan Hukum Kewarisan Islam dalam Lingkungan Adat Minangkabau, (Jakarta: Gunung Agung, 1984), hlm. 169179. 
Praktik-praktik kehidupan adat kelihatannya masih terus berjalan, terutama yang menyangkut dengan masalah warisan, karena harta pencaharian suami masih dibawa menurut ketentuan adat oleh kaumnya, bukan oleh anakanaknya. Evolusi ke arah integrasi adat yang Islami terus berlangsung hingga akhirnya harta pencaharian suami tidak lagi diwarisi oleh kaumnya, akan tetapi diwarisi oleh anak-anaknya. Ini baru terlaksana setelah kemerdekaan Indonesia, di mana terjadinya pendekatan-pendekatan dan musyawarah antara tokoh agama dengan tokoh adat Minangkabau. Dalam musyawarah "urang ampek jiniah alam Minangkabau" tahun 1952 berhasil disepakati, bahwa harta pusaka tinggi yang didapati secara turun temurun menurut garis keibuan diturunkan menurut adat, sementara harta pencaharian yang menurut adat disebut pusaka rendah diwariskan menurut ketentuan syarak. ${ }^{14}$

Karya hukum kewarisan sosiologis lainnya adalah hasil penelitian Abdullah Syah dengan judul "Integrasi Antara Hukum Islam dan Hukum Adat dalam Kewarisan Suku Melayu di Kecamatan Tanjung Pura langkat". Penelitian ini merupakan disertasi beliau pada Pascasarjana IAIN Syarif Hidayatullah Jakarta tahun 1986. Karya ini membicarakan pelaksanaan hukum kewarisan Islam pada masyarakat patrilinial Tanjung Pura Langkat Sumatera Utara.

Pada masyarakat Melayu di Tanjung Pura Langkat yang menganut adat Temenggong, menurut Abdullah Syah proses penyesuaian antara Adat Temenggong dengan hukum kewarisan Islam tidak menimbulkan masalah, karena Adat Temenggong, seperti halnya hukum kewarisan Islam menganut asas individual. Dalam arti, bahwa segala harta warisan dapat dibagikan kepada ahli waris yang berhak. Demikian pula dengan asas bilateral yang dianut Adat Temenggong yang memberikan harta warisan kepada anak lakilaki dan perempuan, merupakan aturan yang sama dengan sistem hukum kewarisan Islam. ${ }^{15}$

Karya lainnya adalah penelitian yang dilakukan oleh Amir Luthfi dan Sudirman cs dari Fakultas Syari'ah IAIN Sulthan Syarif Qasim Pekanbaru tahun 1982/1983 dengan judul "Hukum Adat Waris Melayu Kepulauan Riau". Dalam penelitian tersebut dijelaskan tentang proses pelembagaan hukum waris dalam masyarakat Islam Melayu bersamaan dengan proses interaksi antara hukum Islam dengan hukum adat. Dalam proses interaksi itu, menurut peneliti, hukum Islam mengambil alih posisi hukum adat terutama dalam masalah hukum kewarisan. Dalam realitas sosial masyakarat Melayu, hukum waris Islam lebih melembaga di banding hukum waris adat. Namun demikian,

14/bid, hIm. 180.

15 Abdullah Syah, Integrasi Antara Hukum Islam dan Hukum Adat dalam Kewarisan Suku Melayu di Kecamatan Tanjung Pura Langkat, (Jakarta: PPs IAIN Syarif Hidayatullah, 1986), hIm. 358-365. 
antara kedua hukum itu menempati posisi yang sama dalam struktur hukum yang berlaku dalam masyarakat melayu. Hal ini dikarenakan hukum waris adat menyerap doktrin syari'at Islam. Jika tidak demikian, hukum adat mengalami kekeringan nilai dan norma, sehingga tidak mampu mengindentifikasikan persoalan kewarisan. Untuk mengidentifikasikan perkembangan dan perubahan sosial yang terjadi di dalam masyarakat, hukum adat menyesuaikan diri dengan perubahan itu dengan jalan memasukan unsur-unsur Islam kedalam sistem hukum kewarisannya. Hal ini dapat dilihat dari berbagai aspek kewarisan adat baik menyangkut sebabsebab kewarisan maupun sistem pembagian harta tirkah pusaka bagi ahli waris. ${ }^{16}$

Dalam penelitian tersebut peneliti menyimpulkan bahwa tidak terdapat perbedaan yang signifikan antara hukum waris Islam dengan hukum adat melayu Kepulauan Riau. Hal ini terlihat pada faktor-faktor yang menyebabkan terjadinya hubungan kewarisan antara seseorang dengan yang lainnya, yaitu melalui sebab perkawinan dan hubungan nasab. Hubungan perkawinan yang dapat menimbulkan akibat hukum dalam sistem kewarisan adalah perkawinan yang sah menurut ketentuan hukum Islam, yaitu perkawinan. ayat-ayat al-Qur an dan hadis dimaksud atau atas sistem waris yang diterima oleh Muhammad. ${ }^{17}$ Teori Receptio a Contrario yang digagas oleh Hazairin yang mengatakan, bahwa berlakunya hukum Islam di Indonesia tidak berdasarkan hukum adat, tetapi didasarkan pada penunjukan peraturan dan perundang-undangan tersendiri. Dengan demikian hukum adat baru bisa berlaku jika tidak bertentangan dengan hukum Islam.

Abdullah Syah mengatakan, bahwa integrasi antara adat Temenggong dengan hukum kewarisan Islam di Kecamatan Tanjung Pura Langkat berlangsung dengan cara pengadopsian kewarisan hukum adat dengan memberinya label Islam. Hal ini dimungkinkan karena adanya kesamaan antara kedua sistem hukum tersebut. ${ }^{18} \mathrm{Amir}$ Syarifuddin dalam karyanya yang berjudul, "Pelaksanaan Hukum Kewarisan Islam dalam Lingkungan Adat

16 Amir Luthfi cs, Hukum Adat Waris Melayu Kepulauan Riau, (Pekanbaru: Puslit IAIN Susqa, 1982), hlm. 153.

17 David S.Powers, Peralihan Kekayaan dan Politik Kekuasaan: Kritik Historis Hukum Waris, terj. Arif Maftuhin, (Yogyakarta: LkiS, 2001), cet I, hlm. ix.

18 Abdullah Syah, Integrasi Antara Hukum Islam dan Hukum Adat dalam Kewarisan Suku Melayu di Kecamatan Tanjung Pura Langkat, (Jakarta: PPs IAIN Syarif Hidayatullah, 1986), hIm. 358-365. 
Minangkabau", membagi interaksi kewarisan hukum adat dengan hukum kewarisan Islam kepada tiga macam, yaitu; pertama, adat dan syara' berjalan sendiri-sendiri dalam batas yang tidak saling mempengaruhi; kedua, adat dan syara' menuntut haknya masing-masing hingga keduanya diperlakukan sama tanpa menggeser kedudukan yang lain, bahkan dalam pelaksanaannya salah satu di antaranya menyandar pada pihak lain; ketiga, tahap kompromi dan penyesuaian antara hukum adat dan Islam. ${ }^{19}$

\section{ENKULTURISASI}

Sejak Parameshwara kawin dengan puteri Pasai dan memeluk Islam pada $1400 \mathrm{M}$, maka Malaka menjadi pusat bandar $^{20}$ dunia pusat pengembangan agama Islam ke seantero Kepulauan Nusantara dan Asia Tenggara bersamaan sekaligus dengan introduksi budaya Melayu. Sehingga, definisi Melayu sejak 1400 M itu berbunyi : "Seorang Melayu ialah beragama Islam, yang berbahasa Melayu sehari-hari dan yang beradat-budaya Melayu, serta mengaku dirinya sebagai orang Melayu" (Lukman Sinar, 2003 : 1).

Maka,terbentuklah masyarakat berbudaya Melayu di Thailand Selatan, Semenanjung Tanah Melayu, Singapura, serawak, Brunai, Pesisir Sumatera Timur (Temiang, Langkat, Deli Serdang, Asahan, Labuhan Batu), Riau, Jambi, Bangka, Pesisir Palembang dan Kalimantan Barat di pesisirnya dan sepanjang sungai kapuas. Juga terdapat kemudian pemukiman orang Melayu di alam diaspora di Kamboja, Sri Langka dan Afrika Selatan.

Selain bercirikan Islam, berbahasa Melayu (meskipun dengan berbagai dialek) dan beradat budaya Melayu (Adat bersendi Hukum Syara', Syara' bersendi Kitabullah), juga ditandai dengan Hukum keluarga yang Parental.

Karena letak wilayahnya yang amat strategis di sepanjang Selat Malaka dan laut Cina Selatan, yang menjadi urat lalulitas dari Barat ke Timur jauh, maka masyarakat Melayu sudah ratusan tahun terkena arus globalisasi dan pengaruh budaya berbagai etnis dan bangsa.

Pengaruh itu nyata sekali misalnya adat istiadat, ceremony raja-raja dengan upacara musik Naubat dan sistem perniagaan yang kesemuanya pengaruh Persia. Sistem ketatanegaraan dan Orang Besar pengaruh dan dinasti Mughal di India; pada musik dan tari pengaruh dari Timur Tengah dan Portugis (1511 M), pada teater tradisional seperti Makyong, Merdu, Menora dan Bangsawan pengaruh Siam dan India Selatan; dalam bahasa dan

19 Amir Syarifuddin, Pelaksanaan Hukum Kewarisan Islam dalam Lingkungan Adat Minangkabau, (Jakarta: Gunung Agung, 1984), hlm. 189179.

20 Bandar adalah kota, sebagaimana kota-kota seperti di Indonesia. 
kesusastraan pengaruh arab dan India Selatan, beberapa menu makanan dari Cina.

Orang Melayu sangat toleran dan terbuka menerima pengaruh luar yang dirasa baik dan unggul, kemudian orang Melayu melakukan inovasi sendiri dan melaksanakan alih teknologi (gambus dari Arab, Meriam dari Turki, setinggar dari Portugis, kapal dari Persia, mode pakaian, arsitektur, taktik dalam peperangan, sistem diplomasi dan lain-lain banyak pengaruh dari luar, namun sudah banyak dimodifikasi).

Tetapi yang paling berjaya (sukses) ialah bagaimana orang Melayu selama 500 tahun berhasil menapis pengaruh negatif dari luar yang bisa merusak Jati Diri Melayu. Kejayaan Melayu masa lampau karena ia mempunyai tekad yang tunggal atas keesaan Tuhan dengan tawakkal pada tauhid, sanggup mengharungi lautan ganas, menjalin persahabatan dengan suku bangsa yang ganas dan curiga terhadap orang asing; membawa agama Islam yang damai, membawa budaya Melayu yang toleran dan adil, membawa barang dagangan untuk dijual tidak mencekik tetapi jujur, menyediakan pusat transito dagang, menjadikan bahasa Melayu yang demokratis menjadi bahasa dagang dan pergaulan komunikasi; diminta masyarakat lain untuk menjadi pemimpin (raja) mereka karena lemah lembut dan adil dan membuka masyarakat yang ramah dan terbuka.

Kata adat berasal dari bahasa Arab 'ādah, yang berarti perkataan atau perbuatan yang dilakukan berulang-ulang. Adat seperti dijelaskan mempunyai pengertian dan maksud yang sama dengan 'urf. ${ }^{21}$ Pada masyarakat Melayu, pengertian adat sudah menunjukkan perkembangan dari makna asal. Sebab, kata adat tidak lagi hanya menunjukkan kepada perkataan atau perbuatan yang dilakukan berulang-ulang, akan tetapi mengandung nilai tingkah laku yang seharusnya dipertahankan. Adat bagi masyarakat Melayu-Siak merupakan sistem nilai yang menjadi tolok ukur bagi setiap aktifitas yang dilakukan masyarakat. ${ }^{22}$ Adat sebagai norma bagi masyarakat Melayu-Siak merupakan alat pengikat yang tingkatannya berbeda-beda. Tingkatan-tingkatan dimaksud dapat dibedakan pada tiga macam, yaitu; Adat Sebenar Adat, Adat Yang Diadatkan, dan Adat Yang Teradat.

\section{a. Adat Sebenar Adat}

21 Subhi Mahmassani, Falsafah al-Tasyri' fi al-Islam, terj. Ahmad Soejono, (Bandung: al-Ma'arif, 1981), hlm. 190

22 Wan Galib, (67 tahun, tokoh adat Melayu-Siak), Wawancara, tanggal 5 April 2008. 
Adat Sebenar Adat, yaitu kenyataan yang berlaku pada alam yang merupakan kehendak Allah atau sesuatu yang telah ada dan terus berjalan sepanjang masa. Misalnya, adat air membasahi, adat murai berkicau, adat api membakar, dan sebagainya. Bila diperhatikan hubungan antara sifat dengan yang diberi sifat dalam contoh di atas, terlihat adanya bentuk kelaziman hubungan. Namun, tidak berarti bentuk kelaziman ini tidak dapat berubah sama sekali. Dalam perjalanannya bisa saja terdapat berbagai gesekan yang mengakibatkan kurang bulatnya adat ini. Maka oleh karenanya, kelaziman seperti yang disebutkan di atas, dinamakan kelaziman secara adat. Artinya, kelaziman yang pasti itu suatu waktu dapat tidak berlaku menurut kehendak Allah, karena adanya tekanan atau pengaruh, baik yang datang dari luar maupun adanya penyesuaian-penyesuaian terhadap sesuatu yang baru. Dalam kehidupan sehari-hari Adat Sebenar Adat dapat dilihat, misalnya dalam sistem kekeluargaan, kekerabatan, dan warisan.

Adat merupakan aturan-aturan yang merupakan implementasi dan mengacu kepada ajaran Islam (al-Qur'an dan al-Sunnah). Maka oleh karena itu, keberadaan adat ini memiliki daya ikat yang kuat bagi masyarakat Melayu. Adat yang tidak lain adalah manifestasi dari ajaran Islam, menempati posisi yang paling tinggi dan paling dimuliakan oleh masyarakat MelayuSiak. Sistem nilai yang berasal dari ajaran Islam ini diakui yang paling asasi dan merupakan rujukan dari sitem nilai lainya. Sistem ini berjalan dan dipatuhi masyarakat di daerah ini bukan karena adanya suatu lembaga atau badan tertentu sebagai pengontrol, tetapi lebih didasarkan kepada kesadaran dan kepatuhan masyarakat terhadap perintah agamanya. Oleh karena itu, maka orang yang melanggar Adat Sebenar Adat tidak hanya dipandang sebagai orang yang tidak beradat, akan tetapi juga dianggap orang yang kurang beragama. Dalam pepatah melayu dikatakan;

\author{
"Adat turun dari syara' \\ Diikat dengan hukum syari'at \\ Itulah pusaka turun temurun \\ Warisan yang tak putus oleh cencang \\ Yang menjadi galang lembaga \\ Yang menjadi ico dengan pakaian \\ Yang digenggam diperselimut" \\ "Adat yang keras tidak tertarik \\ Adat yang lunak tidak tersudu \\ Dibuntal singkat, direntang panjang \\ Kalau kendur berdenting-denting \\ Kalau tegang berjela-jela \\ Itulah adat sebenar adat" \\ "Tahu adat sebenar adat
}


Adat berpunca kitabullah

Adat berinduk kepada sunnah

Adat mengikut firman Allah"

Adat Yang Diadatkan adalah sesuatu yang dirancang, dijalankan, serta diteruskan oleh setiap generasi untuk menjadi peraturan bagi kehidupan masyarakat dalam berbagai aspek. Adat Yang Diadatkan dibuat oleh sulthan/ penguasa pada suatu kurun waktu dan adat itu terus berlaku jika tidak diubah oleh sulthan/penguasa berikutnya. Adat ini dapat berubah-ubah sesuai dengan perkembangan zaman dan situasi. Adat ini dapat disamakan dengan "peraturan pelaksana" dari ketentuan Adat Sebenar Adat. Adat Yang Diadatkan ini dibuat berdasarkan mufakat dan musyawarah dan tidak boleh bertentangan atau menyimpang dari ketentuan Adat Sebenar Adat. ${ }^{23}$

Adat Yang Diadatkan merupakan ketentuan yang berisi suruhan dan larangan atau pantangan di dalam komunitas sendiri. Ketentuan-ketentuan ini dapat dilihat dari ungkapan-ungkapan sebagai berikut:

"Tahu adat yang diadatkan

Adat tumbuh dari mufakat

Adat tidak dibuat-buat"

"Adat yang turun dari raja

Adat yang datang dari datuk

Adat yang cucur dari penghulu

Adat yang dibuat kemudian"

Pada awalnya, Adat Yang Diadatkan mengatur hak-hak istimewa para penguasa (raja), para bangsawan atau orang-orang yang memiliki kedudukan --seperti tengku, wan, orang kaya, datuk, syarif, said-- dan masyarakat kebanyakan (orang awam). Peraturan ini meliputi bentuk rumah, bentuk dan warna pakaian, serta atribut-atribut yang digunakan dalam upacara seremonial, seperti perkawinan, kematian, kelahiran, maupun dalam kegiatan ekonomi. Namun, Adat Yang Diadatkan ini sudah mulai ditinggalkan seiring dengan semakin memudarnya makna stratifikasi sosial (pembedaan status sosial kepada kaum bangsawan dan orang kebanyakan), serta sebagai akibat adanya perubahan, baik pada tataran budaya material maupun pola pikir masyarakat. Bahkan, generasi muda Riau tidak banyak mengerti dan mengetahui tentang aturan-aturan Adat Yang Diadatkan ini. Masyarakat di daerah ini tidak lagi begitu mempersoalkan bentuk rumah,

23 Wan Galib, Said Muhammad Umar \& Muhammad Daud Kadir, Adat Istiadat Melayu di Bekas Kerajaan Siak Sri Indrapura, (Pekanbaru:

Lembaga Adat Daerah Riau, 1991), hlm. 123. 
jenis dan warna pakaian yang dapat membedakan kaum bangsawan dan orang kebanyakan. Dewasa ini, bentuk dan keadaan rumah maupun lambang-lambang tradisional tidak lagi menunjukkan pembedaan status sosial mereka. Dahulu, pada masa jayanya Kesultanan Siak, rumah bagi orang melayu tidak hanya sekedar tempat tinggal, akan tetapi juga sebagai lambang kesempurnaan dirinya. ${ }^{24}$

Adat Yang Teradat adalah kebiasaan setempat yang dapat bertambah dan bisa pula lenyap menurut kepentingan. Kebiasaan yang menjadi peraturan ini mulanya dirumuskan oleh ninik mamak pemangku adat di suatu tempat untuk mewujudkan aturan pokok dalam Adat Yang Diadatkan, yang pelaksanaannya disesuaikan dengan situasi dan kondisi setempat. Oleh karena itu, Adat Yang Teradat dapat berbeda antara satu tempat dengan tempat lain menurut keadaan, waktu dan kebutuhan anggotanya. Dalam pepatah Melayu dikatakan;

"Tahu adat yang teradat

Adat tumbuh menengok tempat

Adat dipakai bertempat-tempat"

Dengan demikian, bila dibandingkan antara Adat Yang Teradat dengan Adat Yang Diadatkan terlihat dari segi keumuman berlakunya. Adat Yang Diadatkan bersifat umum pemakaiannya pada seluruh tempat dan wilayah, dalam hal ini Melayu-Riau, sementara Adat Yang Teradat adalah kebiasaan pada masyarakat di suatu tempat dalam wilayah Melayu-Riau, misalnya di daerah Siak Sri Indrapura saja.

Adat Yang Teradat merupakan konsensus bersama yang dirasakan cukup baik sebagai pedoman dalam menentukan sikap dan tindakan dalam menghadapi setiap peristiwa yang terjadi dalam masyarakat. Konsensus ini dijadikan pegangan bersama, sehingga merupakan kebiasaan turun temurun. Adat Yang Teradat juga dapat berubah-ubah sesuai dengan nilai-nilai baru yang berkembang di tengah-tengah masyarakat. ${ }^{25}$ Dalam pepatah melayu dikatakan;

"Adat yang teradat

24Hasrin Saili, (65 tahun, Tokoh masyarakat Riau), Wawancara, tanggal 12 April 2008

25Budi Santoso, Parsudi Suparlan \& Ahmad Yunus, Masyarakat MelayuRiau dan Kebudayaannya, (Pekanbaru: Pemda Riau, 1985), hlm. 504. 
Datang tidak bercerita

Pergi tidak berkabar".

"Adat disarung tidak berjahit

Adat berkelindan tidak bersimpul

Adat berjarum tidak berbenang

Yang terbawa burung lalu

Yang tumbuh tidak ditanam

Yang kembang tidak berkuntum

Yang bertunas tidak berpucuk"

"Adat yang datang kemudian

Adat yang diseret jalan panjang

Yang bertenggek di sampan lalu

Yang berlabuh tidak bersauh

Yang berakar berurat tunggang

Itulah adat sementara

Adat yang dapat dialih-alih

Adat yang dapat ditukar salin"

Termasuk dalam pengertian Adat Yang Teradat adalah kebiasaan-kebiasaan yang berkaitan dengan tingkah laku dan kesenangan yang dalam adat Minangkabau disebut dengan Adat Istiadat. Pelanggaran terhadap Adat Yang Teradat sanksinya tidaklah seberat seperti pada Adat Sebenar Adat dan Adat Yang Diadatkan. Jika terjadi pelanggaran terhadap Adat Yang Teradat, maka terhadap pelanggarnya hanya diberikan teguran atau nasehat oleh orang-orang yang dituakan di tempat itu, misalnya, dari segi berpakaian, cara berbicara atau bersikap. Bila seseorang berkunjung ke suatu tempat, misalnya dia mengenakan pakaian yang tidak lazim di tempat itu, maka dengan cepat masyarakat mengenalnya dan biasanya dipanggil dan ditegur dengan kata-kata "tidak baik begitu caranya di sini, jaga-jagalah sedikit sikap, atau pakaian awak tu, dan sebagainya".

Ketiga tingkatan adat di atas, bila dilihat dari aspek kepastian berlakunya dapat dibedakan pada dua macam, yaitu; pertama, adat yang tidak dapat berubah; kedua, adat yang dapat berubah menurut kepentingan. Adat yang tidak dapat berubah adalah Adat Sebenar Adat. Untuk tingkatan adat ini berlaku pepatah:

"Tidak lapuk karena hujan

Tidak lekang karena panas

Dianjak tidak layu

Diungguk tidak mati

Dialih membinasakan

Dipindah ia merusakkan" 
Sementara adat yang dapat berubah menurut kepentingan adalah Adat Yang Diadatkan dan Adat Yang Teradat. Terhadap kedua bentuk adat ini berlaku pepatah "sekali air bah, sekali tepian beralih". Artinya, Adat Yang Diadatkan dan Adat Yang Teradat dapat menyesuaikan diri dengan suatu perubahan yang terjadi. Selanjutnya dalam pepatah melayu disebutkan;

"Putus mufakat adat berubah

Bulat kata adat berganti

Sepanjang kain ia lekang

Beralih musim ia layu

Bertukar angin ia melayang

Bersalin baju ia tercampak

Adat yang dapat dibuat-buat"

Selain adat, di dalam kehidupan sosial masyarakat Melayu-Siak juga dikenal adanya istilah tradisi. Berbeda dengan adat, sistem nilai tradisi tidak berupa kaidah-kaidah dan peraturan-peraturan, melainkan hanya berupa kebiasaankebiasaan yang disampaikan secara lisan serta tidak memberi sanksi dalam pelaksanaannya. Kebiasaan-kebiasaan tersebut dipandang sebagai tradisi karena adanya unsur kebajikan dan mendatangkan manfaat dalam kehidupan masyarakat. Dalam menjaga keharmonisan dengan alam. Oleh karena itu, kebiasaan itu diikuti dan dilestarikan serta diwarisi secara turun temurun.

Pola kehidupan masyarakat yang masih bergantung kepada alam, telah menyebabkan munculnya tokoh-tokoh tradisi, seperti; Patih, Batin, dan Datuk Kaya. Tokoh-tokoh ini mempunyai peran yang signifikan dalam mengatur lalu lintas kehidupan masyarakat. Kecuali tokoh-tokoh tersebut, tokoh tradisi lainnya yang mempunyai peran dalam kehidupan masyarakat adalah dukun, bomoh, pawang, dan kemantan yang diharapkan mampu menjaga hubungan harmonis antara manusia dengan alam. Hal ini merupakan konsekwensi dari pola pikir masyarakat yang masih tradisional. Sebagian masyarakat Melayu-Siak masih percaya bahwa, laut, tanjung, tanah, pohon, ikan, burung dan binatang liar lainnya dihuni atau dikontrol oleh makhluk halus yang kemampuannya melebihi kemampuan manusia biasa. Makhluk halus yang menunggu tanah disebut "Jembalang", makhluk halus yang mengawal binatang liar dan burung disebut "Sikodi", sedang makhluk halus yang menampakkan dirinya sebagai perempuan cantik disebut "Peri". Sistem nilai tradisi merupakan sistem nilai yang terendah dalam masyarakat Melayu.

Masyarakat Melayu di Riau menganut norma adat dan tradisi secara ketat, sementara pada saat yang sama mengaku sifat komplementaritasnya 
dengan prinsip-prinsip Islam. Di sini terlihat dengan jelas, bahwa kedudukan adat dan tradisi berada di bawah aturan Islam. Oleh karena itu, agama Islam mempunyai pengaruh yang sangat kuat terhadap adat-istiadat melayu. Dalam pepatah adat dikatakan; "adat bersendi syara', syara' bersendi kitabullah, adat ialah syara' semata, adat semata qur'an dan sunnah, adat sebenar adat ialah kitabullah dan sunnah nabi, syara' mengata adat memakai, ya kata syara' benar kata adat, adat tumbuh dari syara', syara' tumbuh dari kitabullah, berdiri adat karena syara"'.U.U Hamidy mengatakan, bahwa dengan datangnya Islam ke daerah Melayu-Riau, maka sistem nilai masyarakat menjadi tiga macam, yaitu; Islam, adat dan tradisi. Ketiga macam sistem nilai ini membentuk semacam piramid terbalik, di mana sistem nilai Islam berada pada tempat yang paling tinggi disusul oleh adat dan kemudian tradisi pada lapisan yang paling bawah. Pola ini memberikan suatu logika, karena sistem nilai Islam menempati kedudukan yang paling tinggi, maka adat dan tradisi yang berada di bawahnya harus merujuk atau menyesuaikan diri kepada sistem nilai Islam. Inilah yang dikatakan adat dan tradisi bersendikan kepada Islam. ${ }^{26}$

Dalam "mitologi Melayu" dikatakan, bahwa adat Melayu-Riau bersumber dari adat Ketemanggungan (Temenggong) yang diletakkan oleh Datuk Ketemanggungan dan Adat Perpatih yang diletakkan oleh Datuk Perpatih Nan Sabatang. Kedua adat tersebut menganut dua sistem kekerabatan yang antara satu dengan yang lainnya saling berbeda. Adat Perpatih menganut sistem kekerabatan matrilineal, yaitu mempertahankan susunan masyarakat atas dasar keturunan ibu. Sementara adat Temenggong mengembangkan susunan masyarakat atas dasar keturunan bapak atau patrilineal. Kedua sistem sosial yang berbeda ini oleh sebagian besar budayawan diyakini berasal dari Minangkabau. Hal ini sesuai dengan pepatah adat yang mengatakan "syara' mendaki, adat menurun". Artinya, agama Islam (syara') datang dari Riau (Siak) ke daerah Minangkabau dengan cara "mendaki", sementara adat datang dari Minangkabau ke Siak dengan cara "menurun". Pemahaman tersebut dilihat dari letak geografis daerah memang demikian, yakni wilayah Siak berada di pinggir pantai, sementara daerah Minangkabau berada jauh di pedalaman. Oleh karena itu, Islam lebih dahulu berkembang di daerah Siak dibanding dengan Minangkabau. ${ }^{27}$ J.A. van Rign van Alkemade, seperti dikutip Amir Luthfi,

26 UU. Hamidy, Islam dan Masyarakat Melayu di Riau, (Pekanbaru: UIR Press, 1999), hlm. 209-211.

27 Amir Luthfi, Hukum dan Perubahan Struktur kekuasaan: Pelaksanaan Hukum Islam dalam Kesultanan Melayu-Siak 1901-1942, (Pekanbaru: Susqa Press, 1991), hlm. 75-76 
mengatakan bahwa orang-orang Minangkabau sudah mendiami pinggir Sungai Siak pada waktu sungai itu masih bernama Sungai Jantan. Merekamereka itu adalah keturunan dari empat orang datuk yang berasal dari Padang Panjang, yaitu Datuk Marpusun, Datuk Sa'i, Datuk Kelantan, dan Datuk Marbadak. Datuk Marpusun dan keturunannya bermukim di Sungai Gasib, Datuk Sa'i dan keturunannya di Senapelan -daerah Kota Pekanbaru sekarang-, Datuk Kelantan di daerah Sungai Kelantan, dan yang terakhir Datuk Marbadak dan keturunannya bermukim di daerah Sungai Kecil daerah Betong. ${ }^{28}$ E.N. Tylor mengatakan, bahwa adat yang berkembang di semenanjung Melayu dan pantai timur Sumatera baik dalam wujud Adat Temenggong maupun Adat Perpatih dipandang berasal dari adat Minangkabau. Adat Temenggong yang terdapat di daerah Siak dan MelayuRiau pada umumnya diambil dari Minangkabau melalui kerajaan Budha Palembang. Di Palembang, Adat Temenggong ini mengalami modifikasi dengan meninggalkan bentuk kesukuan matrilineal berubah menjadi sistem kekerabatan patrilineal. Sementara Adat Perpatih dibawa oleh para imigran asal Minangkabau ke daerah ini yang diduga telah mulai datang tidak lama setelah Portugis dapat merebut Malaka dalam 1511M. ${ }^{29}$ Tenas Effendy, tidak begitu setuju dengan pendapat itu. Menurutnya, yang dimaksud dengan pepatah adat yang mengatakan, "syara' mendaki, adat menurun" adalah berkaitan dengan posisi syara' terhadap adat sebagai sumber nilai dalam kehidupan masyarakat dan bukan indikator proses Islamisasi di suatu daerah. Dalam konteks ini, dominasi syara' (Islam) naik sementara dominasi adat menurun. Artinya, dalam kehidupan bermasyarakat yang menjadi rujukan utama masyarakat Melayu-Siak adalah syara' (Islam), sementara adat harus menyesuaikan dan tidak boleh bertentangan dengan nilai-nilai Islami. Dominasi syara' (Islam) terhadap adat terlihat dengan jelas ketika terjadinya Islamisasi di daerah ini. Setelah Islam masuk dan menjadi anutan masyarakat, Islam telah dijadikan sebagai identitas Melayu dan bahkan terjadi proses "pengislaman" terhadap adat dan tradisi. Dengan demikian, adat dan tradisi yang bertentangan dengan ajaran Islam harus ditinggalkan. ${ }^{30}$ Tenas Effendy, tidak melihat sumber adat Melayu-Siak dari adat Minangkabau. Sebab, masyarakat Melayu di daerah ini tidak mengenal istilah Adat Ketemanggungan dan Adat Perpatih. Masyarakat Melayu juga

$28 \mathrm{Ibid}$

29/bid, hlm. 122-124.

30 Tennas Efendy dan Nahar Effendy, Lintasan Sejarah Kerajaan Siak Sri Indrapura, (Pekanbaru: BPKD, t.t), hIm. 17. 
tidak mengenal salah satu dari sistem adat tersebut baik yang bersifat patrilineal maupun matrilineal. Sebaliknya, masyarakat di daerah ini menganut sistem kekerabatan parental/ bilateral, sekalipun dalam garis genealogis bersifat patrilineal. Akan tetapi tanggung jawab terhadap keluarga dalam kehidupan sehari-hari, bapak dan ibu mempunyai peran dan tanggung jawab yang sama. Tenas, selanjutnya mengatakan bahwa adat Melayu-Siak berasal dari Johor. Sebab, kesultanan Siak merupakan pewaris sah kekuasaan Malaka-Johor. ${ }^{31}$

Menurut Tenas Effendy, sistem kekerabatan yang berlaku dalam masyarakat Melayu-Siak, dan umumnya pada masyarakat Melayu-Riau, sama dengan sistem kekerabatan yang dianut dalam Islam, yaitu parental (bilateral). Sebab pada dasarnya masyarakat melayu tidak membedabedakan antara kerabat bapak dengan kerabat ibu. Mereka semua merupakan satu kesatuan keluarga. ${ }^{32}$ Sebagai masyarakat yang tidak berklan, sistem perkawinan di masyarakat melayu pada dasarnya tidak mengenal istilah kawin endogami atau kawin eksogami, seperti yang terdapat di masyarakat unilateral. Walaupun dalam praktiknya mereka juga melakukan perkawinan dalam bentuk endogami ${ }^{33}$.

$31 \mathrm{lbid}, \mathrm{hlm} .23$

$32 \mathrm{lbid}, \mathrm{hlm} .27$

33 Soerojo Wignjodipoero, membedakan sistem perkawinan kepada tiga bentuk, yaitu; pertama; sistem endogami, yakni mengharuskan seseorang mencari jodoh di lingkungan sosialnya sendiri, lingkungan kerabat, lingkungan kelas sosial atau lingkungan pemukiman. Sistem ini pada prinsipnya jarang terjadi di Indonesia. Pada masa lalu sistem perkawinan ini hanya ditemukan di tanah Toraja. Kedua; sistemeksogami, yakni mengharuskan seseorang mencari jodoh diluarlingkungan sosial, lingkungan kerabat, golongan sosial atau lingkungan pemukiman. Pola ini terdapat di daerah Gayo, Alas, Tapanuli, Minangkabau, Sumatera Selatan dan Seram. Ketiga, sistem eleutherogami, yakni tidak mengenal laranganlarangan seperti dua sistem di atas. Larangan terjadi jika ada ikatan keluarga senasab dan hubungan kekeluargaan seperti yang terdapat dalam hukum Islam. Sistem ini lebih merata terdapat di berbagai daerah hukum adat di Indonesia seperti Aceh, Sumatera Timur, Bangka, Belitung, Kalimantan, Minahasa, Sulawesi Selatan, Ternate, Irian, Timor, Bali, Lombok dan seluruh Jawa dan Madura. Lihat Soerojo Wignjodipoero, Pengantar dan Azas-Azas Hukum Adat, (Jakarta: Masagung, 1982), hlm. 32 
Dari aspek posisi syara' dalam adat melayu, pendapat Tenas tersebut adalah sangat logis. Hal ini sesuai dengan pepatah adat yang mengatakan "adat bersendi syara', syara' bersendi kitabullah". Artinya, adat yang dipandang sebagai sumber nilai dalam kehidupan masyarakat adalah adat yang berdasarkan kepada syara' (Islam), sementara kebiasaan yang tidak berlandaskan hukum syara' tidak disebut adat (Adat Sebenar Adat). Sebaliknya, juga tidak salah bila pepatah adat yang mengatakan "syara' mendaki, adat menurun" diartikan sebagai indikator proses islamisasi di kedua daerah tersebut. Pengertian ini sejalan dengan teori-teori islamisasi yang mengatakan bahwa proses islamisasi dilakukan melalui aktifitas perdagangan. Itu, artinya daerah-daerah yang terletak di pinggir pantai lebih dahulu menerima Islam dibanding dengan daerah-daerah lain yang ada di pedalaman. Sebab, umumnya pusat-pusat perdagangan terletak di tepi pantai. Dengan demikian, daerah Siak yang terletak di tepi pantai lebih dahulu menerima Islam di banding dengan daerah-daerah pedalaman, termasuk Minangkabau.

\section{Ciri-ciri Kepribadian Orang Melayu}

Yang dimaksud dengan ciri-ciri kepribadian Orang Melayu, ialah watak Orang Melayu yang nampak pada umumnya (modal personality), terbentuk watak umum itu tidak terlepas dari tuntutan norma-norma adat istiadat yang terdapat dalam masyarakat Orang Melayu. (Koentjaraningrat, 1970: 130). Tentu saja watak umum dari kepribadian Orang Melayu yang dilukiskan disini adalah watak kepribadian orang Melayu yang ideal dan dianggap baik dengan tuntutan adat istiadat yang berlaku. Penonjolan adat istiadat bukan berarti terlalu etnosentris atau bersifat sempit, namun melihat juga watakwatak yang lemah atau buruk yang terdapat mengerikan, yang sama saja buruknya dengan watak-watak buruk pada manusia mana pun yang berada dalam kebudayaan mana pun. Segala yang buruk dan lemah itu tidak perlu dibeberkan di sini, karena hal yang serupa itu merupakan suatu penyimpangan dan penyakit masyarakat yang senantiasa ada dan dibenci oleh setiap masyarakat.

Adat istiadat Melayu yang dimaksud, adalah semua komplek konsepkonsep serta aturan-aturan yang mantap dan terintegrasi kuat yang terdapat dalam sistem budaya Orang Melayu yang menata tindakan-tindakan anggota masyarakat dalam kehidupan sosial dan kebudayaan tersebut. Kepribadian ini tidak terlepas dari cara orang Melayu melihat dunia sekelilingnya dan melihat dirinya sendiri, serta kesadaran dihadapan agamanya, kesadaran terhadap kebutuhan hidup sehari-hari, kesadaran berada di tengah-tengah orang lain dan orang asing, dan sebagainya yang kesemuanya mencetuskan sikap dan tingkah laku Orang Melayu dalam hal menghormati orang lain yang 
hidup di tengah-tengah masyarakatnya, yang sesuai dengan tuntutan adat istiadatnya.

Hal ini perlu diketengahkan karena banyak orang terutama orang yang bukan Orang Melayu yang keliru menilai kepribadian Orang Melayu. Kadangkadang timbul semacam salah pengertian atau kesengajaan dalam menilai kepribadian masing-masing. Masalah seperti inilah yang perlu dijelaskan sehingga Orang Melayu dinilai secara sinis seperti: Melayu yang berarti lari, sebab Orang Melayu suka mengalah, Orang Melayu perajuk, sebab Orang Melayu suka menjauhkan diri apabila tersinggung, Melayu kopi daun, dan sebagainya. Kata-kata ini selalu dilontarkan orang Belanda (pada jaman penjajahan) untuk menghina orang Melayu. Demikian halnya dengan sifat yang kurang menyenangkan itu selalu dikenakan terhadap Orang Melayu.

Adapun inti ajaran yang selalu diajarkan orang tua kepada anaknya ialah agar menjadi orang yang selalu; (1) tahu diri; (2) sadar diri; (3) sadar diuntung; dan (4) mempunyai harga diri ${ }^{34}$. Keempat hal ini selalu dipompakan kepada anak, agar selalu menjadi orang tahu diri, sadar diri, sadar diuntung dan mempunyai harga diri. Keempat aspek itu berkaitan satu sama lainnya.

Harga diri sebagai tonggak yang selalu ingin ditegakkan dapat dicapai, apabila setiap orang sadar diri dan tahu diri. Orang yang tak tahu diri dan sadar diri tidak akan pernah dapat mempertahankan harga dirinya. Tahu diri berarti orang; (1) tahu akan kedudukannya di dalam keluarga; (2) tahu akan hak dan kewajibannya di tengah-tengah keluarga; (3) tahu asal-usul keturunan keluarga; (4) tahu kedudukan diri dan keluarga di tengah-tengah masyarakat, apakah orang berbangsa (bangsawan) atau orang biasa; dan (5) tahu atau sadar akan keadaan hidup sebagai orang yang tak berpunya; (6) tahu atau sadar akan kewajiban dan tata tertib yang dituntut oleh adat istiadat yang berlaku; (7) tahu atau sadar akan tugas masing-masing yang dipercayakan orang; (8) tahu atau sadar akan kekurangan diri, baik kekurangan pengetahuan, pengalaman, keterampilan, atau pun rupa (bentuk fisik); (9) tahu atau sadar bahwa dunia dengan segala isinya adalah kepunyaan Tuhan; dan (11) tahu atau sadar bahwa hidup hanya sementara (fana).

Dari keempat aspek di di atas menjelma watak Orang Melayu seperti : (1) sifat merendah diri; (2) sifat pemalu atau penyegan; (3) sifat suka damai atau toleransi; (4) sifat sederhana; (5) sifat sentimentil dan riang; dan (6) sifat mempertahankan harga diri. (Daud Kadir, 1986: 514).

Sifat merendah diri ini merupakan sifat yang paling dituntut dalam pergaulan Orang Melayu. Orang selalu merendahkan diri berarti ia tahu diri dan sadar diri. Sifat merendah diri tercermin dari sikap tingkah laku yang

34 Mohd. Daud Kadir dalam tulisan yang berjudul "Pola Penghormatan dan saling memberi Orang Melayu di Riau" 1986. 
tertib, sopan dan hormat. Sikap itu tampak pada gerak geriknya, tutur bahasanya, terutama apabila seorang berhadapan dengan kaum kerabat atau seorang anggota masyarakat yang lebih tua. Bahkan tingkah laku tertib, sopan dan hormat itu harus dilakukan terhadap orang asing. Sikap merendah diri tidak sama dengan sikap menghina-hina diri. Dengan sikap merendah diri justru orang menjaga martabat diri (harga diri). la tidak mau karena sikap dan tingkah laku atau tutur bahasa yang tidak memperhatikan martabat diri. Sikap ini justru yang paling dibenci Orang Melayu. Sikap serupa menunjukkan orang tak tahu diri dan tak tahu diuntung. Sifat merendah diri sangat jelas tampak dalam pepatah Melayu, seperti: "Berkata biar ke bawah-bawah, mandi biar ke hilir-hilir. "jangan bawa sifat ayam jantan, tapi bawalah sifat ayam betina, kalau pergi kerantau orang. (Mahmud Ahmad dalam Daud Kadir, 1986: 516).

Orang Melayu selalu merendah diri bukan saja terhadap orang yang lebih tua, orang besar, pemuka adat, alim ulama tapi juga terhadap penghuni alam sekelilingnya. Oleh karena itulah jika ia lalu (lewat) disuatu tempat yang angker, maka merendah diri sambil berkata: "Tabik datuk, anak cucu numpang lalu". Menurut Orang Melayu dengan cara merendah diri, ia akan selamat. Seandainya ia merasa takut karena seorang diri di laut atau di hutan, ia akan berkata, "Tabik datuk, jangan ganggu, anak cucu cari makan". Oleh karena sifat merendah diri pula nama Melayu diberikan kepada Orang Melayu yang berarti, melayu-layukan diri seperti bunga atau daun yang layu. Bunga yang layu kelopaknya melempai atau terkulai ke bawah. Demikian nama Melayu dikaitkan dengan sifat atau Orang Melayu yang selalu merendah-rendahkan diri.

Sebagai lawan dari sifat merendah diri ialah, sifat yang suka menonjolkan diri, sombong, serba tahu, serba pandai. Sifat ini paling tidak disenangi Orang Melayu, tak boleh menunjuk pandai tak boleh berjalan mendada, tak boleh songkok senget, pendeknya tak boleh sombong dan besar cakap (Mahmud Ahmad dalam Daud Kadir, 1986: 517). Sifat merendah diri ini tampak pula apabila Orang Melayu mengajak tamunya makan, ia akan berkata "Silahkan jemputlah makan encik". Tidak ada apa-apa, makan tak berlauk". Padahal hidangan yang disajikan itu penuh sarat dengan lauk pauk. Jika mengajak tamunya singgah ke rumah, ia akan berkata "singgahlah encik ke gubuk kami yang buruk ini". Padahal rumahnya adalah rumah yang cukup besar, komplit dengan alat perabotannya. Kalau ingin berbicara, maka selalu berkata, "Terlebih dahulu saya minta maaf...".

Sifat pemalu ini juga bertolak dari sifat tahu diri, sadar diri, tahu diuntung dan harga diri. Sifat pemalu ini merupakan sifat yang menjaga harga diri. Sifat pemalu ini tercermin dalam sikap dan tingkah laku seperti: Segan meminta bantuan, segan menonjolkan diri, segan mengadukan kesusahan, segan mengambil muka, segan berebut-rebutan (tamak), segan mendahului orang tua dan sebagainya. Oleh karena itu sifat penyegan ini Sifat Malu 
Dengan demikian jika ingin bergurau, harus dijaga jangan sampai ia merasa malu di tengah orang. Apabila ia tersinggung atau malu, atau merasa dihina (diruntuhkan air mukanya) dihadapan khalayak ramai, maka sifat segannya menjadi hilang, ketika itu juga memperlihatkan reaksi tidak senang, bahkan kadang-kadang ia mereaksi secara kasar demi mempertahankan harga dirinya.

Orang Melayu tahu diri, ia selalu mengerti sikap orang lain, sebagaimana ia menghargai dirinya sendiri. Oleh sebab itulah ia bersikap terbuka dan berlapang dada. Setiap orang yang datang ke kampung halamannya selalu diberi pertolongan. Orang tidak boleh tidur di jalan atau minum di sumur. "Biar rumah sempit, tapi hati lapang". Orang yang dapat menghargai orang lain adalah orang yang berhati mulia. Kebaikan hati akan meningkatkan harga atau martabat diri sekaligus martabat kampung halamannya.

Akibat dari sikap toleransi ini Orang Melayu sangat senang bertolak ansur, tidak cerewet atau banyak cingcong, gampang berurusan. Segalanya lebih kurang saja. Cincai-cincailah kata orang Cina. Sikap suka bertolak angsur dan tidak cerewet itulah yang menyebabkan Orang Melayu disegani para pendatang. Sifat ini jualah yang menyebabkan Orang Melayu sebagai orang yang suka mengalah. Memang ia mengalah karena tidak mau ribut atau terjadi pertengkaran, berselisih paham yang tidak perlu. Bertengkar, berselisih hati, menyebabkan harga diri jadi luntur.

Orang Melayu selalu berfikir sederhana. Mereka tidak mau memikirkan segala sesuatu itu yang rumit dan sulit. Hidup yang berarti selalu dilihat dari segi kesederhanaannya. Sederhana dalam: Pergaulan, memiliki harta, berpakaian dan perhiasan, berkata-kata, bersuka ria, cita-cita, mencari rezki. Sifat kesederhanaan ini juga berpangkal dari sifat tahu dan sadar diri. Orang Melayu sadar bahwa : (1) hidup di dunia ini hanya sementara saja; (2) segala isi dunia adalah milik Tuhan; (3) hidup yang berlebih-lebihan tidak akan membuat hidup bahagia; dan (4) hidup bahagia bukan pada harta, tertanam di hati.

Pandangan yang serupa itulah yang menyebabkan Orang Melayu tenang tidak tergesa-gesa, tidak tamak, tidak serakah, tidak berlomba-lomba mencari harta dan kedudukan. Sifat sederhana ini pula yang menyebabkan Orang Melayu tidak memiliki skala-skala yang besar dalam berusaha dan bersaing dengan orang lain yang datang ke daerahnya. Sikap ini juga yang menjadi kerisauan para cerdik pandai Melayu, sebab jaman sekarang ini tidak lagi berhadapan dengan kehidupan serba lamban, sederhana dengan skala kecil saja. Orang Melayu harus melihat kembali kenyataan-kenyataan yang terjadi di luar dirinya. Orang Melayu harus berpartisipasi aktif memacu diri, dalam sain dan teknologi yang memerlukan cara berfikir lebih maju (future oriented). 
Ada pun suatu pandangan Orang Melayu yang dinilai negatif. Mereka berpendapat bahwa kemiskinan itu merupakan warisan keturunan yang tak dapat diubah. Pandangan ini terlihat dalam pepatah yang berbunyi: "Rezeki secupak tak kan dapat jadi segantang”. Salah satu bait sya'ir berbunyi :

"Jangan banyak fikir-memikir

takdir tidak dapat dimungkir

nasib nak miskin tentulah fakir

bolehlah tadbir menyalahi takdir"

"Rezeki secupak sudah terbentang

kemana dikejar tak dapat digantang

nasib berhutang mesti berhutang

janji nak malang, malanglah datang"

(Daud Kadir, 1986: 518)

Berdasarkan pandangan ini agaknya Orang Melayu kurang bergairah untuk menjadikan dirinya orang kaya. Pepatah lain yang selalu didengungdengungkan oleh orang tua sebagai berikut: "surga bagi orang kafir di dunia ini. Surga bagi kita orang Melayu di Akhirat”. Dengan ajaran ini seolah-oleh tak ada gunanya memperbaiki hidup, berlomba-lomba, berebut-rebut harta, berebut pangkat dan kedudukan, karena semua hal itu bukan untuk orang Melayu. Oleh sebab itu Orang Melayu kelihatan seperti pemalas. Pemalas berarti malas berusaha, malas mencari yang lebih banyak, malas memperbaiki tarap hidup. Dengan demikian mereka puas dengan apa adanya (hidup sederhana).

Konsekuensi dari sifat tahu diri, sadar harga diri, Orang Melayu menjadi orang yang sangat sentimentil. Oleh karena mereka tahu diri akan kekurangan diri, derajat diri dalam stratifikasi sosialnya, maka ia selalu menekan perasaan. Keinginannya dan hasratnya sedaya upaya ditahan agar jangan orang itu tahu dan menyebabkan harga diri menjadi hilang. Untuk menyalurkan getaran dan gejolak perasaannya ia mengungkapkan perasaan yang tertekan itu dalam bentuk lagu-lagu yang sedih, dalam nada-nada dan rentak yang sentimentil. Akan tetapi ia tidak terlalu larut dalam kesedihan yang tidak berkesudahan. Kesedihan dan kemalangan itu disalurkan pula dengan rentak dan nada gembira seperti yang tercermin dalam rentak dan lagu-lagu berirama joget, patam-patam, mainang dan zapin, sebab Orang Melayu sadar bahwa meratap dalam kesedihan tidak akan mengubah nasib yang sudah ditaqdirkan. "Apa guna kita bersedih, lebih baik kita bersuka ria". Ini satu imbangan dari sifat sentimentil yang mewarnai corak watak kepribadian Orang Melayu.

Di atas diuraikan sifat Orang Melayu yang baik dan menyenangkan. Hal itu terpancar dalam setiap interaksi tersebut terjadi semacam kemacetan komunikasi yang disebabkan ketidakcocokan watak yang menyertai orang 
yang sedang berkomunikasi itu. Kemacetan komunikasi itu sering terjadi karena tidak ada sikap saling menghargai. Sikap tidak menghargai, berarti menghilangkan harga diri. Apabila salah seorang yang sedang berkomunikasi itu merasa hilang harga diri, maka ia merasa tersinggung. Dalam keadaan tersinggung ia akan mengambil sikap protes yaitu dengan cara memutuskan hubungan sebagai tanda protes. Sikap ini dikenal dengan istilah merajuk.

Merajuk berarti dia menutup diri untuk membicarakan masalah yang menyebabkan perasaannya tersinggung. Sikap merajuk itu diperlihatkan sebagai tanda ia tidak setuju terhadap sikap, tingkah laku dan pandangan orang yang menyinggung perasaannya itu. Apabila sikap merajuk yang diperlihatkan itu tidak dihargai, bahkan diremehkan, maka ia akan mengambil sikap menjauhkan diri. Kadang-kadang ia pindah kekampung lain atau negeri lain. Menjauhkan diri bertujuan menghindarkan pertemuan dengan orangorang yang telah menyinggung perasaannya. Sikap merajuk atau menjauhkan diri diambil apabila ia merasa tidak perlu memperpanjang soalsoal kecil yang kurang berarti demi mempertahankan harga diri.

Namun demikian apabila di dalam interaksi terjadi sesuatu penghinaan atau pencemaran yang menjatuhkan harkat dan martabat diri seseorang, maka hilangnya harga diri itu akan dijawab dengan sikap amuk atau mengamuk. Mengamuk, ialah suatu sikap yang diputuskan untuk membela harga diri yang telah dicemarkan oleh seseorang. Harga diri itu dinilai tercemar apabila, seseorang diberi malu (aib) yang tak mudah dihapuskan dalam waktu singkat. Perbuatan-perbuatan yang dipandang amat mengaibkan seseorang antara lain: Anak perempuan dicemarkan orang, istri dilarikan orang, istrinya kedapatan bermain serong, kaum kerabatnya dihina orang. Dengan kata lain sikap amuk itu timbul apabila ia merasa dirinya telah dipecundang atau dicabar orang. Akan tetapi tidaklah semua hal-hal tersebut menimbulkan sikap amuk, karena sikap amuk adalah satu sikap yang paling akhir yang dapat dilakukan. Apabila memutuskan untuk mengamuk demi membela harga dirinya, ia harus mendahului dengan suatu sumpah (sesumbar). Sesumbar atau sumpah bertujuan untuk menimbulkan semangat, membulatkan tekad, menambahkan kekuatan dan sekaligus mengumumkan kepada masyarakat bahwa sikap itu telah menjadi keputusan yang tidak boleh ditarik lagi. Dengan sesumbar berarti, telah memilih jalan akhir memulihkan harga dirinya yang berarti ia akan memutuskan segala hubungan dengan dunia dan masyarakat. Tekad amuk hanya mempunyai dua pilihan yang semuanya negatif, yaitu, mati atau masuk penjara.

Oleh karena itu sebelum memutuskan sikap amuk, seseorang harus kembali kepada sikap tahu diri dan sadar diri dengan cara mempertimbangkan semasak-masaknya atas segala akibat yang ditimbulkan oleh perbuatan amuk. la harus mempertimbangkan dirinya sendiri, anak istrinya, keluarganya, sanak saudaranya dan sebagainya. Apabila diambil 
keputusan amuk maka berarti ia hanya bertekad untuk mati atau menderita (dipenjara).

Tekad untuk mati inilah yang menyebabkan cara berpikir sikap dan tindakannya berubah. Perubahan itu menyebabkan ia menjadi liar, kasar, bengis, tak perduli, tak terkontrol, bertekad membunuh, untuk memuaskan naluri yang paling buas. Dalam keadaan serupa itu, jiwa orang tersebut menjadi abnormal, hilang keseimbangan, pandangan tidak jernih. la disebut naik pitam, dalam hatinya bersemi marah dan tekad membinasakan. Dalam keadaan yang serupa itu, ia tidak lagi dapat membedakan siapa lawan dan siapa kawan. Sikap ini menjadi lebih gila apabila korban telah jatuh. Untuk menghalanginya ia harus dihindari atau dibinasakan. Oleh sebab itu sikap amuk itu amat jarang terjadi, sebab apabila seseorang telah sesumbar, senjata telah diasah atau dicabut, maka ia harus melaksanakan, kalau tidak ia akan disebut pengecut.

Pengecut berarti harga diri lenyap. Maka itulah sesumbar dan menarik senjata amat langka dilakukan. Orang lebih suka bersikap sabar atau mengalah daripada mengamuk. Disinilah orang berkesimpulan orang Melayu sabar atau suka mengalah, sebab dengan sikap inilah ia dapat mempertahankan harga dirinya.

Sikap amuk ini paling tidak disukai oleh orang Melayu. Sikap ini bersifat irrasional, yang tidak humanis. Sikap ini sebagai sifat kontras dengan sifat-sifat lain yang amat luwes (fleksibel), dan menyenangkan.Menurut kamus antropologi, pengertian saling memberi dan saling menerima berkaitan dengan perasaan, martabat seseorang dan penghormatan (penghargaan) terhadap diri sendiri (Charles Winick: 231).

Berdasarkan pengamatan dan hasil laporan para ahli sosial budaya, terutama para ahli antropologi, menjelaskan bahwa hampir diseluruh masyarakat manusia ditemui gejala saling menghormati dan saling memberi. Dengan kata lain pola saling menghormat dan memberi itu merupakan gejala hakiki yang ditemukan dalam kehidupan manusia sebagai makhluk sosial. Namun demikian gejala tersebut bukanlah suatu aktivitas yang sama dan seragam pada setiap masyarakat. Keseragaman pola dan saling memberi serta saling membantu dan mengasihi terbentuk dalam kontek nilai-nilai budaya yang berlaku. Dengan demikian setiap pola penghormatan dan saling memberi terdapat dalam tiap-tiap masyarakat manusia itu bersifat unik. Unik berarti satu-satunya tidak ada kesamaannya dengan yang lain.

Begitu juga halnya dengan pola menghormati dan saling memberi yang terdapat di dalam masyarakat Orang Melayu di Riau. Gejala tersebut tidak terlepas dari pada nilai-nilai adat istiadat Melayu yang membentuk karakter serta perasaan-perasaan yang menyertai setiap tindakan yang tampak dalam setiap interaksi yang terjadi.

Seperti telah disebutkan di atas bahwa pola penghormatan dan saling memberi adalah salah satu dari gejala sosial. Artinya kegiatan tersebut terjadi 
di dalam situasi interaksi antara seseorang dengan orang lain atau sekelompok orang. Namun demikian berdasarkan pengamatan dan pengalaman yang dilakukan bahwa pola penghormatan dan saling memberi yang hidup dalam masyarakat orang Melayu itu dikenal dengan istilah menanam budi, menabur budi atau membuat budi. Ketiga istilah tersebut mempunyai arti yang sama. Selanjutnya akan diuraikan di bawah ini pengertian menanam budi.

Menurut Orang Melayu, budi itu baik. Menanam budi berarti melakukan perbuatan yang baik-baik yang dilakukan seseorang kepada orang lain (Mahmud Ahmad, 1965: 171). Di dalam melakukan perbuatan baik itu, tersirat perasaan memupuk persahabatan, kasihan ingin membantu dan ingat. Menanam budi dapat juga disebut berbuat budi. Menanam budi itu erat kaitannya dengan sifat Orang Melayu yang tahu diri dan mempertahankan harga diri.

Orang yang tahu diri dan ingin mempertahankan harga dirinya akan selalu melakukan penanaman budi. Semakin banyak seseorang menanam budi berarti semakin mulialah hati dan martabatnya dipandang orang. Dengan kata lain, semakin banyak memberi maka semakin tinggilah budi seseorang. Dengan kata lain, semakin banyak memberi maka semakin tinggilah budi seseorang. Selain dari pada beberapa sifat, suka menanam budi ini merupakan salah satu sifat yang paling menonjol dalam kehidupan pribadi setiap Orang Melayu. Di dalam menanam budi itu terkandung nilai kebaikan sebagai nilai tertinggi dalam pandangan hidup Orang Melayu. Buruk baiknya perangai atau watak seseorang selalu dinilai dari budi yang diberikannya kepada orang lain.

Jika diamati dengan seksama, gejala menghormati dan saling memberi dalam masyarakat Orang Melayu itu tampak dalam tiga kegiatan yang saling berkaitan antara satu dengan yang lainnya yaitu :

1) Menanam budi (memberi)

2) Menerima budi (menerima)

3) Membalas budi (membalas atau mengembalikan)

Menanam budi dapat disebutkan juga membuat budi atau menabur budi. Orang yang menanam itu disebut penanam budi. Seperti telah diuraikan terdahulu bahwa menanam budi yang dilakukan oleh sipenanam budi bertujuan hanyalah untuk berbuat baik. Sipenanam budi memberikan sesuatu yang dimiliki dipandangnya layak disertai pula dengan niat yang ikhlas untuk memberikan sesuatu kepada seseorang yang dinilai patut (layak untuk menabur budi). Adapun jenis-jenis budi yang bisa diberikan antara lain mencakup sebagai berikut : (1) benda-benda; (2) tenaga; (3) sopan santun; (4) tutur bahasa dan tegur sapa; (5) kunjung mengunjung; (6) pinjang meminjam; (7) tanda mata; (8) menjemput makan; (9) suruh seraya (10) mintak pialang (11) mintak bagi; dan (12) mintak. 
Dalam kontek, kedua belas situasi interaksi inilah seseorang memiliki peluang untuk menanam budinya kepada orang lain. Agar kedua belas situasi ini jelas, maka berikut ini diuraikan satu persatu secara singkat. Dari kedua belas situasi yang tersedia itu dapat pula dibagi dalam dua kategori, yaitu:

1. Pemberian yang diberikan oleh sipenanam budi

2. Pemberian yang diminta oleh orang yang ingin menerima budi

Pada katagori pertama kegiatan menanam budi (memberi) secara aktifnya datang dari sipenerima budi, yang termasuk, dalam kategori ini antara lain, memberi benda-benda (tenaga ada yang diberi ada yang diminta), sopan santun, tutur bahasa dan tegur sapa, kunjung mengunjung, pinjam meminjam, tanda mata, dan menjemput makan.

Pada katagori kedua, kegiatan menanam budi (memberi) itu tidak berawal dari si pemberi budi akan tetapi budi itu diminta dengan sengaja oleh si penerima budi. Jelas yang termasuk dalam katagori ini antara lain: suruh seraya, mintak pialang, mintak bagi, dan mintak.

Benda yang biasa diberikan sebagai alat penanam budi termasuk; makanan, buah-buahan, hasil bumi, hasil laut, hasil perburuan dan oleh-oleh. Pemberian benda-benda itu diperhatikan pula jenis makanan, jenis buahbuahan, jenis hasil bumi, jenis hasil laut dan jenis oleh-oleh yang dibawa. Dengan kata lain pemberian itu haruslah memperhatikan: kualitas, kelangkaan, perasaan kebersamaan, tanda ingat. Faktor kualitas itu perlu diperhatikan agar benda-benda yang diberikan itu dalam keadaan baik (bentuk, rasa, rupa). Pepatah Melayu mengatakan: jika ingin berbudi kepada orang, berikanlah barang yang terbaik, janganlah memberi barang yang sudah tidak terpakai. Benda-benda itu dapat juga diberikan apabila memang amat langka (seperti air zam-zam). Dalam keadaan langka benda itu tidak lagi diperlukan bentuk, rasa dan jumlah patokannya. Jika masih dapat dimakan dapat diberikan kepada orang.

Pemberian benda-benda yang langka ada kaitannya dengan perasaan kebersamaan, oleh karena benda itu langka, harus dibagi sedikit sama sedikit, yang penting semua orang (tetangga) dapat merasakan. Dalam keadaan yang serupa itu yang dipentingkan adalah perasaan bersama. Jangan sampai memutihkan mata, mehampakan dada, terutama terhadap anak-anak. Pemberian yang sedikit itu sebagai simbol tanda ingat. Artinya si pemberi tidak melupakan orang lain yang menjadi sahabatnya. Pemberian yang mengandung nilai tanda ingat, bukanlah karangan yang dinilai, akan tetapi perasaan dari si pemberi yang ingat itu yang dipentingkan. Si pemberi benda-benda itu sadar benar akan dirinya agar tidak terperangkap dalam sifat lokek atau tamak. Sifat tamak mencerminkan sifat tak tahu menanam budi.

Tenaga dipakai juga untuk menanam budi. Mempergunakan tenaga sebagai alat menanam budi dapat dilakukan, terutama oleh orang-orang yang tidak memiliki benda (materi berhasrat menahan budi kepada seseorang 
yang disenangi. Dengan tenaga itulah ia memberikan bantuan atau pertolongan kepada orang yang mengaharapkan bantuannya, tenaga yang diberikan itu dapat berbentuk:

1. Membantu ketika seseorang sakit

2. Membantu berganjal (sejenis gotong-royong), (mengambil ramuan kayu rumah atau kayu bakar hutan).

3. Membantu ketika orang mengadakan pesta (perkawinan, berkhitan, memotong rambut, dan berjenis-jenis kenduri)

4. Membantu ketika suatu kemalangan sedang menimpa suatu keluarga (kematian)

Namun, memberikan tenaga sebagai alat menabur budi dibedakan antara tenaga yang diberikan dan tenaga yang diminta. Kedua hal tersebut sangat berkaitan erat dengan sikap tahu diri dan sadar diri.

Tenaga secepatnya diberikan kepada orang yang memerlukan seperti, mengunjung orang sakit, melayat orang yang kemalangan (kematian). Akan tetapi tenaga tidaklah diberikan begitu saja kepada orang yang sedang mengadakan pesta. Orang tidak akan memberikan tenaganya jika tidak diundang melalui undangan yang biasa dilakukan menurut adat.

Sopan santun adalah sikap tingkah laku yang halus, tertib yang selalu tampak ketika berintegrasi. Sikap dan tingkah laku yang halus tercermin dari gerak-gerik: kepala, mata, bibir, bahu, tangan, jari, badan, kaki, air muka, cara berpakaian. Sopan santun dilakukan kepada, kedua orang tua (ibu dan bapak), angota kerabat, orang-orang tua dalam masyarakat, pemimpinpemimpin masyarakat.

Gerak-gerik yang halus itu tercermin pula ketika: bersalaman, berbicara, menunjuk, menghadap orang tua, makan bersama, berpakaian, berjalan dan sebagainya. Tingkah laku yang dinilai tertib, penuh sopan santun dan penuh penghormatan antara lain :

1. Jika berbicara dengan ibu bapak tidak boleh keras-keras berbicara dengan menyebut diri saya atau nama diri dengan panggilan kesayangan orang tua seperti "Are", "Dayang" dan sebagainya. Jika laki-laki, waktu bicara memakai songkok (peci) duduk bersila, jika perempuan bersimpuh.

2. Jika mau lalu (lewat) dihadapan orang tua-tua atau orang tua sedang bercakap atau tamu-tamu terhormat yang sedang duduk-duduk bercakap, maka orang yang lalu (menumpang lalu) menundukkan badannya sambil tangan kanan di bawah ke depan sedang tangan kiri, diletakkan di bawah pergelangan tangan kanan seolah-olah mengangkat tangan kanan itu, sambil berkata "Tabik saya numpang lalu", dengan berjalan lambat-lambat sambil tumit diangkat sedikit sehingga badan bertopang pada bagian depan kaki. Maksudnya agar gerakan itu lembut dan tidak mengeluarkan suara, dan tidak mengganggu orang tua yang sedang berbicara.

3. Jika ingin mempersilahkan orang atau orang yang amat dihormati masuk ke rumah atau ke suatu majlis, maka tuan rumah atau orang yang 
bertugas menyambut tamu mulai itu dengan cepat mendahului datang menyongsong kedatangan tamu sambil badan direndahkan, berjabatan tangan, tangan kanan ditelentangkan, tangan kiri dibawah pergelangan tangan kanan.

4. Jika bersalaman badan dibungkukkan, tangan kanan memegang telapak tangan kanan, tangan kiri menempel di bawah pergelangan tangan kanan. Kemudian tangan kanan ditarik dengan lembut, ujung jari kanan disentuhkan ke dahi, kemudian ujung tangan berpindah menyentuh ke dada agak ke kiri. Artinya orang yang bersalaman itu benar-benar menghargai dan menghormati tamunya dengan hati yang tulus ikhlas putih bersih. Orang yang dihormati itu sangatlah dimuliakan. la diterima sehormat-hormatnya, didudukkan di tempat yang layak di rumahnya dengan cara yang paling sesuai dengan perasaan hormat di penerima tamu.

5. Jika ia menunjuk sesuatu terhadap orang tua atau tamu terhormat, ia akan menggunakan ibu jari kanan, sambil tangan kiri menempel di bawah pergelangan tangan. Jari telunjuk hanya dipergunakan ketika orang marah menuding seseorang yang sedang dimarahi.

6. Jika berpapasan dengan orang tua, orang yang muda menyapa terlebih dahulu. Hendak kemana Pak Ngah. "Ketika ia menyapa ia berhenti di pinggir jalan. la meneruskan perjalanan setelah orang yang dihormati itu melewatinya.

7. Kalau bertemu dengan orang tua yang membawa beban berat, orang muda diwajibkan mengantarkan beban orang tua itu hingga sampai ke rumah. la harus menunda dahulu perjalanannya. Kecuali orang tua itu menolak karena ia tak mau mengganggu perjalanan anak muda tersebut. Apalagi kalau ia bertemu dengan orang tuanya sendiri yang sedang membawa beban berat. la harus mengantarkan beban itu ke rumah. Jika orang muda (laki-laki) bertenu seorang gadis di jalan, jika ia kenal, ia harus menyapanya dengan tegur sapa yang halus. Tidak boleh berhenti untuk berbicara, kecuali jika gadis itu masih kaum kerabatnya. Namun tetap tidak boleh bergurau atau berceloteh panjang lebar dengan suara besar. Jika hal ini terjadi, tingkah laku yang serupa itu dianggap tidak sopan atau sumbang. Tingkah laku sumbang ialah tingkah laku pergaulan laki-laki dan perempuan yang melanggar adat-istiadat. Sumbang ini dapat juga berupa sumbang kata, subang tingkah, sumbang niat, dan sumbang pergaulan.

8. Ketika makan, masing-masing orang ikut makan bersama hanya duduk bersila. Yang muda menyendokkan nasi membagi-bagikan kepada orang yang lebih tua. Ketika makan, berpakaian yang sopan dan pakai peci (bersongkok). Jika tidak mempunyai peci, harus dicari gantinya, umpamanya dengan cara meletakkan sebatang rokok atau segulung kertas kecil diantara celah daun telinganya. Ketika makan tidak boleh berbicara kuat-kuat, tidak boleh berbicara yang kotor dan menjijikan 
(menggelikan), tidak boleh berludah atau berdahak (membuang lendir di mulut) dan sebaginya. Jika orang muda selesai makan, ia harus menunggu orang yang lebih tua selesai, setelah itu barulah ia mencuci tangannya. Menurut tata tertib makan lama, apabila makan lauknya kerang rebus, maka kerang itu harus dibuka dengan sebelah tangan yaitu tangan kanan. Jika ingin membalik ikan itu haruslah minta ijin terlebih dahulu kepada yang lebih tua. Ketika mengangkat hidangan atau meletakkan kembali haruslah dilakukan dengan cara yang paling sopan. Pada saat tingkah laku sopan santun ketika makan itu telah banyak mengalami perubahan. Sudah banyak orang Melayu yang makan sambil duduk di kursi, hidangan dihidangkan atas meja. Pada beberapa keluarga modern sudah ada pula yang menggunakan sendok garpu seperti orang Barat.

Demikianlah orang yang sopan, tertib dan halus dalam bersikap dan bertingkah laku terhadap orang lain, berarti ia telah memberikan budi dalam bentuk penghormatan.

Kedua hal tersebut dapat dipisahkan antara yang satu dengan lainnya. Tutur bahasa ialah yang halus serta suara yang lembut dipergunakan ketika berbicara dengan orang lain terlebih-lebih kepada orang tua dan orang yang dihormati. Bahasa yang dipakai, terutama panggilan terhadap diri masingmasing dipergunakan istilah yang tepat baik dari segi pangkat (jenjang beradarkan strata sosial) maupun umur dan jenis kelamin.

Yang dimaksudkan dengan tegur sapa ialah keramahtamahan dalam menyapa atau menegur sesorang dengan bahasa dan sapaan yang tepat dan hormat. Orang yang peramah disebut baik tegur sapanya atau tidak berat mulut. Orang yang tidak peramah disebut berat mulut. Demikian tutur bahasa dan tegur sapa itu dinilai juga sebagai alat penanam budi. Orang yang halus tutur bahasanya dan baik tegur sapanya disebut orang berbudi karena mencerminkan hati yang baik.

Kunjung-mengunjung datang ke rumah tetangga atau ke rumah sahabat kenalan merupakan tanda keramahan hati. Berkunjung ke rumah seseorang menunjukkan keihklasan hati yang diiringi sikap bersahabat atau bersaudara.

Kunjung-mengunjung merupakan salah satu bentuk dari menanam budi. Kunjung-mengunjung yang baik selalu berlaku seimbang. Artinya kedua kenalan atau sahabat yang setara, baik usia, pangkat, selalu saling berkunjung ke rumah masing-masing. Dengan kata lain kunjung-mengunjung yang baik selalu saling membalas. Akan tetapi kunjung-mengunjung hanya dilakukan oleh orang muda terhadap orang yang lebih tua. Kunjungmengunjung ini merupakan keharusan ketika hari raya. Kunjung-mengunjung dapat dilakukan setiap hari pada waktu yang dianggap tepat menerima kunjungan, kecuali tengah malam dan subuh hari. Waktu kunjungmengunjung tak perlu diberitahukan terlebih dahulu. Menurut pepatah 
Melayu, "Pintu setiap saat terbuka untuk menerima orang, baik siang maupun malam."

Semakin banyak tamu yang datang ke rumah seseorang menandakan tuan rumah disukai, dihormati karena selalu berlapang dada. Berlapang dada berarti suka menerima kunjungan dengan hati yang jernih dan ikhlas. Sebaliknya, rumah yang jarang dikunjungi orang, karena tuan rumahnya kurang lapang dada. Artinya kurang suka menerima kunjungan. Rumah orang yang seperti disebut "Tangga rumahnya berlumut", karena jarang diinjak kaki orang. Demikianlah kunjung-mengunjung itu merupakan salah satu bentuk dari pada pola saling menghormati dan saling menanam budi.

Pinjam-meminjam merupakan suatu kegiatan interaksi sosial yang selalu tampak dalam kehidupan Orang Melayu. Saling Pinjam-meminjam untuk memenuhi kebutuhan seketika, seperti kekurangan bahan-bahan memasak dan korek api tak pernah, sekalipun dipakai istilah meminjam. Namun meminjam uang dikembalikan setelah orang yang meminjam mendapatkan uang penggantinya. Dalam kegiatan pinjam-meminjam ini juga tersedia bagi orang yang ingin menanam budi.

Pinjam-meminjam itu akan saling balas-balasan. Pinjam-meminjam itu terjadi apabila sesorang berada dalam keadaan sesak. Sesak berarti berada dalam situasi yang sangat memerlukan sesuatu yang sangat dibutuhkan pada saat itu. Meminjam hanya dilakukan dalam keadaan lepas sesak. Orang yang mau meminjamkan seseorang dalam keadaan sesak, disebut orang yang dapat melepas sesak. Orang yang seperti itulah yang disebut orang berbudi.

Tanda mata merupakan suatu pemberian kepada seseorang yang dikasihi. Tanda mata dapat berupa perhiasan, pakaian atau senjata. Tanda mata merupakan lambang kasih sayang atau kenang-kenangan agar si pemakai selalu ingat kepada si pemberi. Oleh karena itulah tanda mata merupakan benda-benda yang tahan lama yang dapat dipakai, disimpan atau dijadikan perhiasan. Kadang-kadang pemberian tanda mata yang semacam itu diserahkan apabila kedua mempelai datang menyembah (sungkem) ke rumah sanak keluarga dekat. Dengan demikian jelaslah tanda mata merupakan alat untuk menanam atau menabur budi.

Sudah menjadi kebiasaan pula yang terdapat dalam masyarakat Orang Melayu yaitu, kebiasaan menjemput (mengundang) orang makan di rumahnya. Orang diundang makan itu biasanya kaum kerabat dekat yang baru datang dari tempat jauh, sahabat kenalan akrab yang baru saja bertemu setelah sekian lama berpisah, dan sahabat-sahabat dekat yang disenangi. Ada tiga kriteria terhadap seseorang yang dikenal : Pertama, kenalan yang boleh ke rumah dan boleh diperkenalkan dengan seluruh keluarga; Kedua, kenalan yang hanya boleh dibawa minum di kedai kopi saja. Orang serupa ini jangan dibawa ke rumah, apalagi diperkenalkan kepada keluarga; dan 
Ketiga, kenalan yang hanya dikenal di jalan saja. Terhadap orang ini, tidak boleh diajak minum ke kedai kopi apalagi dibawa ke rumah.

Kenalan yang dijemput makan ke rumah adalah yang benar-benar akrab dan dapat dipercaya. Menjemput makan ini pun adalah salah satu bentuk menanam budi kepada orang yang dijemput atau diajak makan.

Suruh seraya, adalah memohonkan bantuan yang diminta oleh seseorang kepada orang yang diminta secara halus. Disini terlihat bahwa penanam budi tidak berasal dari orang ingin menanam budi, tetapi diminta oleh orang yang ingin menerima budi. Suruh seraya ini biasanya dalam bentuk tenaga. Dalam interaksi suruh seraya itu terjadi saling memberi dan menerima budi.Mintak pialang istilah yang dipakai untuk minta tolong belikan sesuatu benda atau barang dengan mempergunakan uang orang yang diminta tolong itu. Uang itu akan diganti setelah barang atau benda yang dipesan itu sampai. Mintak pialang ini juga adalah sejenis penanam budi yang dapat diberikan kepada orang yang meminta bantuan.

Minta berarti minta. Minta dilakukan apabila orang meminta sesuatu baik benda, buah-buahan, hasil bumi dan sebagainya. Mintak hanya dilakukan kepada orang yang amat dikenal. Mintak tak dapat dilakukan terhadap sembarang orang. Apabila dilakukan kepada orang yang tidak dikenal atau kurang akrab, maka perbuatan mintak itu sangat menjatuhkan harga diri.

Akan tetapi jelaskan dalam proses mintak itu, orang yang memiliki barang atau benda dapat kesempatan untuk menanam budi. Dari uraian ini juga terlihat bahwa Orang Melayu sangat menghargai dan mengutamakan budi. Budi lebih penting dari materi. Materi atau benda adalah alat untuk menanam atau berbuat budi. Sebagai contoh betapa kuatnya menanam budi atau menabur budi itu menjadi salah satu watak orang Melayu dapat dipelajari dari pantun-pantun atau nyanyian yang mendambakan penanam budi.

Pulau Pandan jauh ke tengah

Gunung Daik bercabang dua

Hancur badan dikandung tanah

Budi baik terkenang juga

Pisang emas bawa berlayar

Masak sebiji di atas peti

Hutang emas dapat dibayar

Hutang budi dibawa mati

Dari Penyengat ke tanjung Pinang

Sarat dengan ubi keladi

Adik teringat abang terkenang

Karena ingat bahasa dan budi 
Musalmah memakai sanggul

Turun ke sawah menanam padi

Emas sekoyan dapat ku pikul

Aku tak sanggup menanam budi

Puas sudah menanam ubi

Nenas juga disukai orang

Puas sudah menanam budi

Emas juga dikenang orang

(Daud Kadir: 1985: 528)

Berdasarkan pantun-pantun di atas terlihat betapa budi menjadi ukuran kebaikan seseorang. Kadang-kadang budi itu tidak dihargai oleh si penerima budi. Budi yang diberi itu tidak dikenang, apalagi dibalas. Dalam keadaan yang serupa itulah si pemberi budi meratap, merajuk, karena si penerima budi lebih menghargai uang dan ringgit dari pada budi. Pemberian budi memang tidak selalu berjalan mulus, kadang-kadang yang diberikan itu mendatangkan rasa sedih, tersinggung. Kesal karena ia tidak diterima sebagai mana yang diharapkan. Pemberi budi itu mempunyai dua motif : Pertama, Pemberian itu bermotif berbuat baik semata-mata, agar diingat dan dikenang orang; dan Kedua, pemberian itu bermotif mengharapkan suatu pembalasan. Penanam budi seperti inilah yang dapat mempersulit orang yang menerima budi.

Penanam budi sebagai ciri pola saling memberi yang telah mendarah mendaging dalam kehidupan Orang Melayu tidak mempunyai motif untuk saling bersaing mengangkat martabat atau gengsi dipandangan masyarakat. Ada anggota masyarakat yang melakukan kegiatan saling memberi dengan cara saling berlomba-lomba untuk meningkakan martabat diri (Marcel Mauss, 1969: 18).Budi yang diberi oleh si penanam budi, ditujukan kepada orang lain. Orang lain itu antara lain: saudara sekerabat, tetangga, sahabat karib.

Orang yang menerima budi itu disebut penerima budi. Semakin banyak ia menerima budi, maka ia akan merasa semakin banyak berhutang-budi.

Menurut adat istiadat Melayu, budi yang diberikan haruslah diterima dan dihargai sebagai tanda penghargaan. la menyampaikan ucapan terima kasih. Kadang-kadang ucapan terima kasih disampaikan dalam bentuk ungkapan "Terima kasih daun keladi, kalau lebih minta lagi". Apakah pemberian budi itu ditolak, berarti orang yang menolak budi itu tidak ingin menjalin persahabatan, tidak mau dibantu, ditolong, atau dikenang (ingat). Berarti ia mampu berdiri di tengah masyarakat. Orang yang tidak menerima budi dinilai tinggi hati (sombong), angkuh, harga diri amat tinggi. Penolakan budi merupakan suatu pernyataan sikap tidak bersahabat. 
Oleh sebab itulah penerimaaan budi itu walau bagaimana pun kecilnya budi, haruslah diterima agar si pemberi merasa senang, puas dan tidak malu-malu atau kehilangan muka.

Orang yang banyak menerima budi seseorang, tanpa dapat membalas secara seimbang terhadap budi yang telah dilimpahkan kepada dirinya pribadi atau keluarganya disebut sudah termakan budi atau menanggung budi. Orang yang sudah termakan budi dari seseorang, biasanya merasa amat berhutang budi. Hutang budi merupakan pantun Melayu tidak dapat dihargai dengan apa pun, ia tidak dapat dibayar dengan uang ringgit, karena ia mengandung kebaikan yang sudah dilunasi. Oleh sebab itulah budi itu tak akan dapat dibalas sampai mati. Budi itu akan dibawa ke kubur bersama penerimanya. Sebaiknya kebaikan budi akan terkenang selalu, sekalipun jasadnya hancur dikandung tanah. Oleh karena budi itu tak dapat dilunasi, maka budi itu mengikat batin si penerima budi terhadap si pemberi budi. Kadang-kadang si penerima budi mendapat kesulitan karena terlalu banyak menerima budi, karena pada suatu ketika si pemberi budi mengharapkan sesuatu dari si penerima budi, namun permintaan sulit untuk dipenuhi. Akan tetap karena si penerima telah banyak termakan budi, maka ia terpaksa dengan segala keberatan hati meluluskan permintaan itu. Disinilah letaknya kesulitan yang dihadapi oleh orang yang telah banyak menerima budi atau termakan budi. Oleh sebab itulah kadang-kadang penanam budi dijadikan alat untuk mendapatkan sesuatu imbalan (balasan) dari si penerima budi. Penanaman budi yang seperti inilah yang menyimpang dari tujuan penanaman budi yang sesugguhnya. Dalam hal yang serupa itu si penerima budi harus berhati-hati. Jika tanda-tanda itu telah kelihatan, ia harus waspada dan haruslah berusaha mengelak menerima budi yang serupa itu dengan cara yang amat halus, agar di pembuat budi tidak kehilangan muka. Seperti kata pantun Melayu :

Turun ke sawah menanam padi

Hendak dijual ke Pekan Lama

Jangan suka menanggung budi

Kerap kali jadi binasa

Walaupun orang tahu ada penanam budi yang menimbulkan kesulitan, namun si penerima budi dengan cepat dapat membedakan mana budi yang sesungguhnya, mana budi yang palsu.

Sesuai dengan tujuan menanam budi yaitu untuk berbuat baik, maka si penerima budi tidak ada kewajiban untuk membalas budi seseorang. Akan tetapi setiap orang yang menerima budi merasa berkewajiban membalas kebaikan yang diberikan itu dengan kebaikan pula. Membalas budi itu sebagai tanda si penerima budi tahu membalas budi. Membalas budi itu dapat dilakukan dalam berbagai bentuk pemberian, jemputan, bantuan 
tenaga, pengabdian, sopan santun, tegur sapa dan pengobatan. Dengan kata lain pembalasan budi itu disesuaikan dengan kemampuan seseorang.

Sebaliknya sehungan dengan membalas budi ini dikenal istilah orang tak tahu membalas budi. Orang yang disebut tak tahu membalas segala kebaikan (budi) yang diberikan oleh seseorang kepadanya, tapi dibalas dengan sikap dan tingkah laku yang berlawanan, seperti mencemarkan nama si pemberi budi, melupakan budi dengan cara tidak mau menghormati, menegur, menyapa, datang berkunjung, bicara dengan kata kasar dan sebagainya. Kadang-kadang perbuatan tak tahu membalas budi itu tampak dalam tingkah laku yang lebih kasar dan keras. Dengan kata lain orang yang tak tahu membalas budi itu tak mengingat sedikit pun budi baik yang telah diterimanya. Orang yang menjadikan tempat makan menjadi tempat berak (buang air besar) adalah orang yang tak tahu membalas budi.

Perbuatan tak membalas budi itu apabila diketahui oleh orang lain yang pernah memberi budi disebut kedapatan budi. Kedapatan budi berarti melakukan perbuatan yang tidak layak atau tak pantas yang ditujukan kepada seseorang yang pernah memberi budi. Perbuatan tidak pantas itu biasanya dapat mencermarkan nama, menfitnah, menganiaya, menipu dan sebagainya.

Orang yang kedapatan budi itu biasanya dinilai berperangai tidak baik yang tak perlu dijadikan sahabat. Orang yang kedapatan budi disebut dalam ungkapan sebagai berikut :

- Menggunting dalam lipatan

- Pagar makan tanaman

- Membesarkan anak buaya

- Susu dibalas dengan tuba

- Musuh dalam selimut

- Di luar lurus di dalam bengkok

Orang yang tak tahu membalas budi memiliki sifat-sifat licik, curang, palsu dan sebagainya. Orang yang kedapatan budi tidak akan pernah membuat budi atau menanam budi.

Pola penghormatan dan saling memberi yang dikenal dengan saling menanam budi itu masih tetap hidup dalam masyarakat Orang Melayu Riau hingga saat ini. Bahkan kebiasaan saling menghormati dan saling memberi itu tidak hanya berlaku terhadap sesama Orang Melayu saja, akan tetapi juga terhadap suku bangsa lain dan orang asing terutama orang Cina yang sudah lama menetap di daerah ini.

Orang Melayu mengirim kue-kue buatannya sendiri kepada sahabatnya orang Cina yang sedang merayakan tahun baru. Sebaliknya demikian pula orang Cina membalas budi baik itu dengan mengirimkan bahan mentah untuk membuat kue seperti, tepung, terigu, telur ayam, 
mercun, bunga api dan sebagainya kepada sahabatnya Orang Melayu yang sedang merayakan Hari Raya.

Kebiasaan memberi dan saling menghormati ini telah mentradisi yang terjalin dalam hubungan Orang Melayu dan orang Cina dalam masyarakat Orang Melayu hingga saat ini. Hingga saat ini kebiasaan menanam budi belum luntur dalam kehidupan Orang Melayu. Kebiasaan itu sudah merupakan suatu adat kebiasaan yang telah meresap dan merupakan salah satu ciri sifat Orang Melayu. Sifat ini dapat dinilai positif maupun negatif, tergantung dari sudut mana orang menilainya.

Untuk melihat relasi antara nilai etik yang orang Melayu pedomani dalam kehidupan keseharian dengan kecenderungan kuat pada nilai kebersamaan (ukhuwah) dan sangat kecil pada dorongan untuk maju (quwwah) atau menguasai. Dapatlah dipetakan pada tabel berikut :

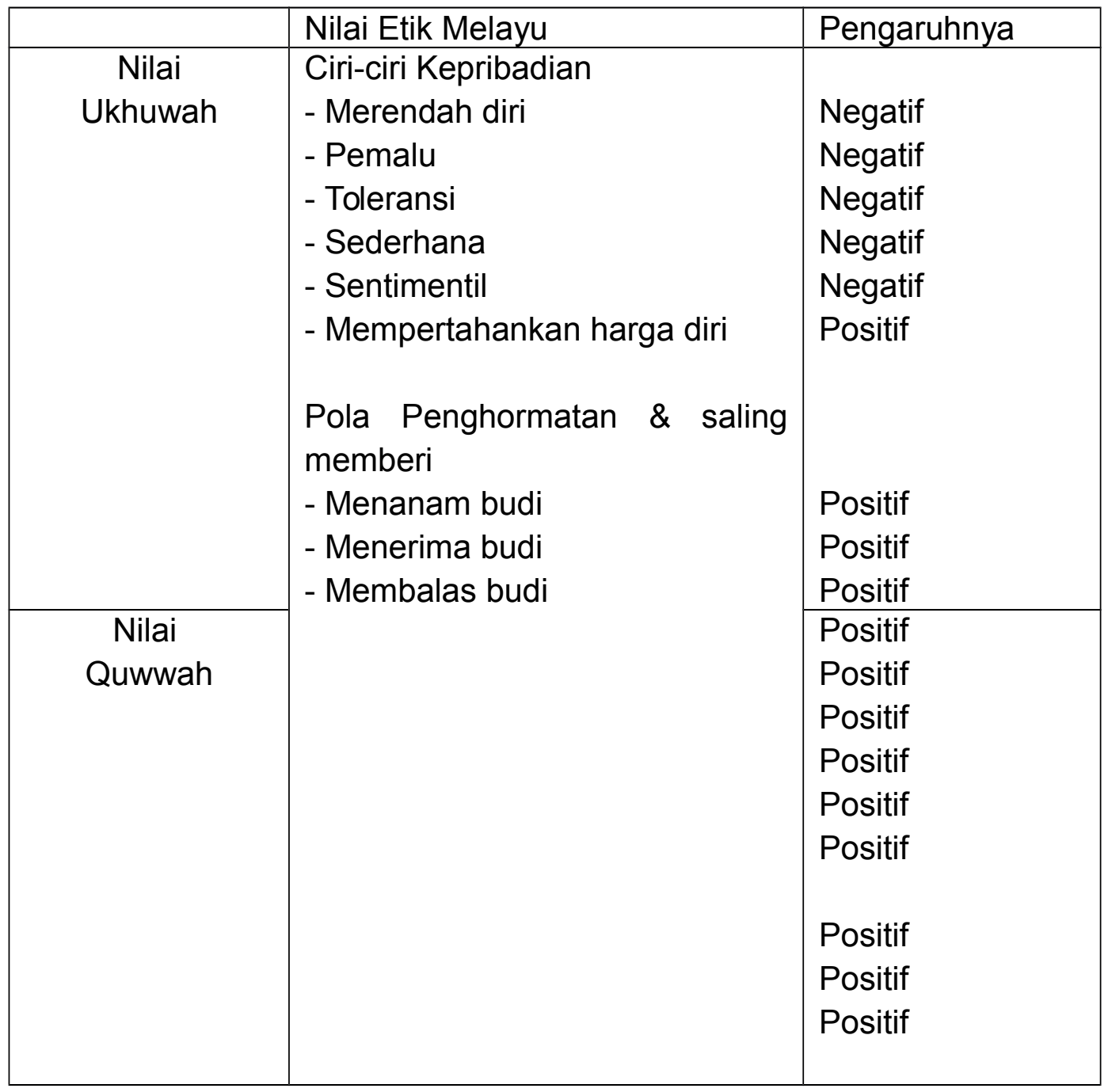


Sumber : Hasil Olahan Data Primer dan Sekunder, 2006

Dilihat dari nilai etik kepribadianya Orang Melayu memiliki nilai persahabatan yang sangat kuat, sehingga mereka sangat terbuka pada para pendatang dan sangat jarang membuat konflik. Namun, sisi lain tidak diimbangi dengan dorongan yang kuat untuk ke arah kemajuan. Sikap cenderung mengalah, tidak ngotot dalam menguasai harta yang terlihat pada sikap kesederhanaannya. Mungkin dapatlah dibuat suatu kesimpulan, bahwa ketika nilai-nilai etik kepribadian Orang Melayu tidak lagi dipedomani oleh masyarakat, baik oleh Orang Melayu sendiri atau pun para pendatang, maka dalam kondisi seperti ini Orang Melayu lebih suka pergi ke hilir sungai (sikap mengalah), artinya mereka akan meninggalkan keramaian kota (bandar) pergi ke kampung-kampung. Jadi, memelihara nilai-nilai etik Melayu jauh lebih penting daripada harus mengubah jati diri, karena sikap kemajuan yang tidak berlandasakan nilai Melayu dianggap merusak harga diri, dan itu adalah jauh lebih penting.

\section{Aktualisasi Kebudayaan Melayu Di Riau}

Manusia memerlukan dua aspek penting dalam hidupnya, yaitu sistem nilai dan budaya. Sistem nilai mungkin sebagian sebagai karya budaya manusia, tetapi yang terbaik adalah yang datang dan Allah melalui Rasul-Nya. Sistem nilai merupakan seperangkat norma yang dijadikan oleh manusia sebagai pedoman dalam berbuat dan bertingkahlaku. Dengan sistem nilai manusia membentuk pandangan hidup, yaitu apa yang dipandangnya benar dan balk, yang akan menjadi pegangan hidupnya. Pandangan hidup inilah yang nanti menentukan sikap setiap berhadapan dengan realitas. Sikap yang diambil akan menentukan pula tindakan atau perilaku. Dan perilaku dengan hasilnya itulah yang kemudian membentangkan sosio-kultural kehidupan manusia.

Budaya menjawab tantangan hidup manusia yang ujud dalam berbagai realitas, ruang dan waktu. Karena itulah budaya menjadi pengejawantahan atau aktualisasi daripada sistem nilai yang telah dianut dalam pen kehidupan. Budaya pada satu sisi menjadi semacam basil penafsiran seperti yang digambarkan oleh perilaku. Pada sisi lainnya sebagai pelaksanaan daripada sistem nilai dalam kehidupan sosio-kultural. Itulah sebabnya pada satu belahan budaya kelihatan sebagai kreativitas manusia, sementara pada ujungnya kelihatan sebagai basil kreativitas itu sendiri.

Agama Islam sebagai pegangan hidup dan mati oleh puak Melayu di Riau, pada satu sisi juga telah menjadi pedoman dan pegangan dalam berbagai situasi kehidupan. Setelah agama inii dilaksanakan dalam bentuk syariat sebagai kewajiban pokok tiap insan, juga telah ditafsirkan begitu rupa sebagaimana kelihatan dalam penampilan sosial budaya. Maka sebagian daripada penafsiran itu telah mengendap menjadi norma dan nilai, sebagian 
lagi menjadi kerja budaya dengan citra Islam.

Orang Melayu di Riau mengatakan agama Islam itu dapat dipakai untuk hidup serta dapat pula ditumpangi untuk mati. Ini berarti bahwa agama Islam dengan segala aspeknya yang multi dimensional, bisa dipakai untuk menyelesaikan perkara dan kepentingan hidup. Tetapi juga dapat diharapkan untuk menghadapi ajal. Inilah agama dalam pandangan orang Melayu yang mampu memberikan serta memenuhi segala hajat dan cita kehidupan.

Adat atau undang-undang karya budaya manusia hanyalah setakat menjawab beberapa aspek kepentingan dunia. Itupun tidak tuntas olehnya. Adat berupa aturan dan sanksi buatan manusia inii hanyalah sekedar mengatur manusia dengan manusia dalam berbagai pergaulan hidup. Begitu pula resam atau tradisi, hanyalah memberi panduan bagaimana manusia berhadapan dengan alam sekitarnya. Maka tetaplah ada suatu hal yang paling prinsip, yang belum terjawab, yaitu bagaimana manusia berhubungan dengan Maha Pencipta yaitu Allah. Maka agama Islamlah 4alam pandangan orang Melayu yang bisa memberikan tali berpilin tiga yaitu hubungan manusia dengan manusia, manusia dengan alam sekitarnya yang terbuhul semuanya dalam hubungan manusia dengan Khaliknya.

Bagaimana agama Islam memperoleh posisi sentral dalam kehidupan orang Melayu, tentulah tidak terjadi secara kebetulan saja. Sebelumnya orang Melayu telah berpegang kepada kepercayaan Animisme-Dinamisme sebagai warisan leluhur mereka. Bekas kepercayaan mi masih mudah dijumpai dalam resam (tradisi) Melayu. Selepas itu mereka memperkaya animisme-dinamisme dengan kepercayaan Hindu-Budha. Dalam hal mi orang Melayu dengan mudah menerimanya, sebab hampir tak ada beda prinsip antara kedua kepercayaan itu. Keduanya sama-sama hasil rancangan leluhur, sehingga kekuatan dan semangatnya hanya semata-mata berada pada mitos-mitos tentang leluhur itu.

Setelah orang Melayu bersentuhan dengan agama Islam, maka mereka terpaksa meninjau kembali kepercayaan yang dianutnya semula. Hasilnya mereka lihat, betapa rapuhnya berpegang kepada kepercayaan yang berisi mitos semata. Sementara misteri hidup dan mati begitu besar dan hebat. Tidak ada yang dapat menjawab misteri hidup dan mati dengan begitu tepat, memuaskan dan meyakinkan, kecuali Islam. Inilah agama yang benarbenar tanpa keraguan. Itulah yang telah terjadi terhadap orang Melayu, yang membuat mereka pindah dahan dan kepercayaan leluhur yang dipadu oleh Hinduisme kepada agama Islam dengan kandungan tauhid yang benar.

Setelah terjadi interaksi) antara Islam dengan budaya Melayu maka berjalanlah proses penyerapan agama Islam dan budayanya, mengikuti kondisi sosial budaya orang Melayu. Penerimaan itu berjalan bagaikan akar kayu menembus tanah. Memang relatif lambat, tetapi mantap. mi terjadi pertama-tama bukanlah oleh para pemegang teraju kerajaan tetapi yang lebih mendasar adalah, betapa unsur-unsur ajaran Islam ternyata 
bersesuaian dengan unsur-unsur antropologis orang Melayu. Persesuaian antara ajaran Islam dengan berbagai unsur antropologis Melayu inilah yang segera membuat agama mi bersebati dengan orang Melayu. Akibatnya Melayu bagaikan islam itu sendiri oleh puak lain yang non Islam di Nusantara.

Kondisi antropologis Melayu telah membuat mereka memberikan penafsiran terhadap Islam dengan cara dan gayanya pula. Dengan kondisi antropologisnya itu kultur Melayu telah menerima agama Islam dengan memberikan tekanan paling kurang kepada 5 perkara. Ajaran Islam yang menganjurkan akhlakul karimah, diterima oleh orang Melayu dalam kondisi budaya mereka yang menghargai budi bahasa. Ajaran Islam yang membimbing manusia untuk mencapai insan kamil bertemu dengan nilai antropologis Melayu harga diri yang kemudian setelah Islam dianut lebih terkenal dengan kata marwah. Islam menganjurkan janganlah melampaui batas. Norma mi bersesuaian benar dengan penampilan orang Melayu yang sederhana. Ketika agama Islam memesankan dunia akhirat, maka bersebatilah ini dengan nilai harmonis dalam dunia Melayu. Kemudian ajaran tutis baca bertemu dengan sanggam akan kesukaan orang Melayu kepada bercerita dan mengarang. Tulisan Arab yang dibaca melalui Al Qur'an segera diubah - suai menjadi tulisan Arab-Melayu, yang kemudian menjadi alat pengembangan karya tulis.

Setelah puak Melayu di Riau (bahkan juga di tempat lainnya) memeluk agama Islam dengan teguh, maka terjadilah suatu kegiatan budaya yang mengalir begitu rupa, menuju muatan yang Islami. Dalam hal mi ada tiga aspek yang layak diketengahkan. Pertama tindakan terhadap kebudayaan Melayu yang telah lama diamalkan sampai mereka memeluk Islam, yaitu adat dan resam. Yang kedua memperkaya budaya Melayu dengan budaya Islam. Ketiga kegiatan budaya Melayu sebagai hash penghayatan dan penafsiran mereka terhadap agama Islam. Ketiganya ini tidak selalu dapat dipisahkan lagi dengan tegas dalam penampilan budaya puak Melayu. Sebab tiap penampilan budaya tidak hanya memperlihatkan satu sisi (jenis) budaya saja, tetapi selalu cenderung dengan sifat yang totalitas, sehingga sulitlah memisahkan diantara ketiga aspek kegiatan budaya-tersebut.

Menghadapi adat yang mengatur tata hubungan kehidupan manusia yang bermuatan ketentuan dan sanksi, puak Melayu memberi dasar Islam, agar tingkah laku adat tidak sampai bertentangan dengan ajaran Islam. Maka norma norma adat sedapatnya bersendikan kepada syarak (hukum Islam) atau sekurangnya tidak melanggar ketentuan ajaran agama itu. Kebenaran syarak tak diragukan ( karena bertumpu kepada wahyu Allah) sebab itu dapat dipakai sebagai dasar untuk menimbang manakah nilai-nilai adat yang layak dipelihara.

Dengan adat bersendi syarak itu tampillah adat Melayu yang dapat diterima oleh ajaran Islam. Perhatikanlah misalnya adat pertunangan Melayu. 
Jika lelaki yang ingkar, dia kehilangan semua tanda pertunangan. Sebab sebagai pembalas malu terhadap perempuan (bekas tunangan lelaki itu) semua benda yang dipakai sebagai tanda pertunangan menjadi milik perempuan itu. Sebaliknya jika perempuan yang ingkar maka dia harus mengembalikan tanda pertunangan dua kali lipat kepada lelaki bekas tunangannya.

Dalam beternak dan berladang puak Melayu pernah membuat adat atau ketentuan 6 bulan mengurung atau mengembalakan ternak, dan 6 bulan lagi baru melepaskan ternak. Dengan cara ini petani aman mengerjakan ladangnya, sementara peternak juga nanti mendapat kelapangan memakai bekas ladang yang sudah dituai dijadikan tempat memberi makan ternak( padang rumput).Dan tiga contoh adat Melayu itu telah dapat dinilai, bagaimana adat mereka telah bersendikan kepada ajaran Islam. Nilainilainya cukup membayangkan mengandung keadilan dan kebenaran. Oleh kandungan nilainya yang demikian itulah orang Melayu telah memelihara adat yang mulia ini.Menghadapi resam (tradisi) yang banyak bermuatan kepercayaan Animisme-Hinduisme, orang Melayu melakukan proses Islamisasi beberapa langkah. Resam yang amat mengesan sekali dalam kehidupan diberi baju atau kulit Islam, sehingga zahirnya bisa kelihatan Islami, meskipun batinnya belum. mi dilakukan antara lain terhadap manteramantera (monto) yang bernafaskan Animisme-Hinduisme. Mantera yang serupa itu dibuka dengan memakai kata Bismillah dan diakhiri dengan nama Allah dan Muhammad. Dengan cara mi arah mitos mantera diharapkan tidak lagi semata-mata terhadap makhluk halus (hantu, jembalang, pen, mambang dan jin ) tetapi sudah kepada Allah dan Rasul-Nya. Atau sekurang kurangnya masih diakul kekuatan makhluk halus itu, namun tetaplah kemampuannya barn dapat berkenan dengan izin Allah. Sebab kekuasaan Allah telah dipandang membatasi kekuasaan dan kekuatan segala makhluk.

Untuk menghindari peranan makhluk halus melebihi kekuasaan Allah, maka pedukunan Melayu sebagai yang paling kental menyerap resam Melayu telah dibetulkan iktikadnya dengan rangkai kata yang Islami, penyakit tidak membunuh obat tidak menyembuhkan. Ini memberi petunjuk bahwa tidak ada kekuasaan termasuk kekuasaan makhluk halus yang dapat menyembuhkan, menyakitkan dan mematikan, melamnkan kekuasaan Allah semata. Penyakit dan obat hanyalah sebagai penyebab belaka untuk berlakunya kudrat dan iradat Allah. Namun tanpa sebab itupun semuanya juga akan berlaku dengan kehendak Allah.

Berhubungan dengan itu orang Melayu membuat semacam mantera yang bernama tawar dan doa untuk menggeser dan menggantikan mantera yang tahayul. Tawar dan doa adalah karya budaya Melayu untuk menggantikan mantera, berupa pantun-pantun atau bahasa berirama yang dirangkam dengan nama Allah dan Muhammad. Malah ada lagi bentuk yang lebih tinggi dan in yaitu lemu. Lemu ( ilmu) merupakan semacam penafsiran 
khas terhadap ayat Qur'an dan sirah Nabi, sehingga dan situ diharapkan terbuka beberapa rahasia gaib, yang dapat digunakan oleh manusia untuk memperoleh kekuatan ruhani. Dengan mempergunakan tawar (misalnya tawar letup oleh api) sesuatu menjadi berubah dan keadaan yang tidak biasa menjadi alam kembali. Sebagaimana artinya, tawar berarti tidak apa-apa; tidak panas, tidak dingin, berada dalam keadaan semula jadi. Karena itulah dengan memakai tepung tawar (ramuan yang telah ditawari) sesuatu (seseorang) tetap berada dalam keadaan balk. Tidak terjadi apa-apa yang menyebabkan berubahnya sifat dan keadaannya. Doa juga demikian. Dengan memakai doa (misalnya doa pandang, penggentar bumi dsb) seorang yang membacanya merasakan lebih percaya din.

Tentu saja upaya puak Melayu memberi citra dan muatan Islam kepada adat dan resamnya belumlah final. Tetap masih ada sisa atau bagman yang belum sepenuhnya membayangkan keislaman. Hal mi sebagian tentulah oleh faktor kemampuan puak Melayu dalam perjalanan ruang dan waktu mempergunakan potensi budayanya menapis dan mengubah-suam adat dan resam itu. Dalam hal ini peranan ulama atau cendekiawan Melayu akan cukup menentukan. Tetapi dengan semakin majunya berbagai lembaga pendidikan Islam, adat dan resam Melayu niscaya akan semakin Islam. Meskipun agaknya masih memerlukan beberapa generasi.

Aktualisasi kebudayaan Melayu Islam dalam kehidupan puak Melayu di Riau juga telah ujud dengan cara memperkaya budaya Melayu dengan budaya Islam . Berbagai syair dan mitologi yang dituturkan oleh ulama dan pengarang Islam dari keturunan Arab dan Parsi telah diaktualisasikan kedalam budaya Melayu oleh ulama di Riau.

Dan upaya Islamisasi karya budaya warisan leluhur yang terkandung dalam adat dan resam, disusul dengan memperkaya budaya Melayu dengan karya budaya Islam asal Timur Tengah dan Parsi, akhirnya puak Melayu di Riau mempunyai potensi budaya yang memadai untuk menampilkan budaya Melayu yang Islami. Ini dapat dilihat dari aktualisasi orang Melayu dalam bidang budaya yang bersifat material atau bendawi. Dalam hal ini puak Melayu pertama telah membuat surau. Surau merupakan karya budaya Melayu yang amat penting bagi pembinaan dan perkembangan agama Islam dalam masyarakat. Di surau inilah budak-budak Melayu belajar mengaji Al Qur'an.

Di samping surau yang dipakai untuk belajar mengaji setelah sembahyang Magrib sampai waktu isya, maka pada petang hari orang Melayu menyelenggarakan madrasah atau sekolah Arab untuk pelajaran tulis baca Arab-Melayu serta ilmu- ilmu islam yang pokok. Tetapi peranan surau bagi puak Melayu tidaklah hanya sekedar tempat melakukan pendidikan membaca Al Qur'sn saja. Benda budaya mi juga menjadi sarana sosialisasi bagi anak muda :Melayu. Surau juga dipakai sebagai tempat tidur oleh 
budak-budak remaja Melayu para duda yang telah bercerai dan suami yang tengah bersengketa dengan isterinya, bahkan juga ada orang tua-tua. Dengan peranan ini, maka bisa pula terhindar kemungkinan inses (hubungan kelamin antar saudara) dan pelanggaran seksual lainnya dalam kalangan keluarga.

Penampilan yang merangsang hawa nafsu disebut juga oleh orang Melayu sebagai cabar. Penampilan yang demikian dipandang merendahkan harga dir Bagi penampilan yang tidak merangsang itu orang Melayu telah merancang baju kurung, tekuluk dan selendang untuk kalangan perempuan. Sedangkan untuk lelaki menjadi tradisilah memakai kain sarung, balk untuk melakukan sembahyang maupun untuk menghadiri berbagai pertemuan dan upacara di kampungnya.Khatam Al Qur'an juga merupakan penampilan budaya Melayu yang berpijak kepada ajaran Islam. Untuk membangkitkan minat anak-anak Melayu mempelajari kitab suci agama Islam itu, maka bagi mereka yang sudah tamat (khatam) diaraklah dengan suatu upacara yang meriah. Anak-anak yang khatam itu dibuatkan kerenda dengan motif yang bermacam-macam, seperti burung, perahu, mobil, kapal terbang dsb. Setelah diberi pakaian yang indah-indah, mereka masuk kedalam kerenda, lalu diarak sepanjang jalan di kampung itu dengan iringan musik rebana atau gambus . Upacara ini lazimnya disudahi dengan makan bersama dan pembacaan doa.Musik tradisional Melayu di Riau mempunyai 3 jenis alat yang penting, yaitu gendang, gitar zapin ,biola dan akordion.

Selanjutnya marilah kita perhatikan pula penampilan budaya Melayu dengan denyut Islami dalam kegiatan bahasa. Pertama orang Melayu mengatakan bahwa bahasa adalah pertanda bagi budi pekerti. Dalam hal mi amat terkenal satu diantara bait gurindam Raja Au Haji jika hendak mengenal orang yang berbangsa lihat kepada budi bahasa. Karena itu sulit bagi orang Melayu untuk menampilkan dirinya dengan bahasa yang kasar. Adalah untuk menjaga penampilan yang lemah lembut itu jugalah orang Melayu telah banyak memakai pepatah, peribahasa (bahasa yang dihaluskan) penumpamaan dan pantun. Semuanya ini memakai lambang dan kias. Akibatnya berbagai perkataan dan ucapan yang kasar serta kecaman, dapat menimbulkan suasana konfrontatif. Dengan bahasa lambang dan kias komunikasi dapat berjalan tanpa membangkitkan emosi yang negatif. Bagi orang Melayu memang terhadap manusia cukuplah dipakai kias untuk mengajarnya, sebab ia mempunyai akal budi dan bisa menimbang dengan benar dan tuntunan agama. Kekerasan atau kalimat yang tajam tidak layak. Yang terakhir ini cukuplah untuk binatang. Sebab secara fitnah manusia tahan kias dan binatanglah yang tahan palu.

Bagi orang Melayu bahasa merupakan darah dan daging bagi kehidupannya "Sebagaimana diucapkan juga Sutardji Calzoum Bachri " Presiden Penyair Indonesia" asal Melayu Riau itu. Tak heran jika Sutandji sebagai seorang penyair piawai Melayu setara dengan Hamzah Fansyuri, 
Raja Ali Haji dan Amir Hamzah, amat kecewa berpisah dengan bahasa Melayu yang pernah jadi nafas dan semangat budayanya. Bahasa yang begitu lentur dan kaya dengan lambang dan kias. Sekarang dia terpaksa memakai bahasa Indonesia yang kasar, tiada intonasi yang mengalun bagaikan ombak lautan senja jauh dan semangat batin.

Kentalnya dimensi bahasa dan kebudayaan dalam budaya Melayu di Riau, telah mendorong suburnya budaya . Para tukang cerita yang semula banyak dan kalangan pawang, bomo dan dukun, setelah Islam mereka anut, bengeser kepada para ulama. Para ulama telah mengambil peranan yang luas dalam sejarah budaya Melayu. Di samping sebagai ulama yang mengajarkan agama Islam kepada warganya, ulama juga telah menjadi pengarang, menulis berbagai kitab. Baik mengenai ilmu-ilmu Islam yang pokok maupun mengenai cabang budaya lainnya seperti sejarah, hukum, bahasa, kebudayaan dsb.

Dalam dimensi bahasa dan kebudayaan $\mathrm{ml}$ baiklah lebih dahulu kita ketengahkan pertunjukan berdah yang biasanya dibacakan dengan suara yang mendampingi oleh rebana dan musik gambus Inilah penampilan budaya Melayu yang melukiskan betapa cintanya mereka kepada Junjungan Alam, Nabi Muhammad Saw. Syair yang berisi peristiwa kelahiran junjungan Alam mi dibacakan dalam berbagai versi dan iringan musik dalam berbagai acara sosio religius. Satu diantaranya dalam bentuk tertulis Arab-Melayu berasal dari Raja Ali Haji dengan judul Syair Sinar Gemala Mestika Alam. Berbagai hasil budaya Melayu biasanya mempunyai teks berdah. Teks ini dibacakan bersama-sama atau bersahut-sahutan. Perhatikanlah Beberapa contoh kutipannya dan matan rudah (berdah) Rantau Kuantan.

Keliling pasang pelita

Umpama bintang cahayanya

Semalam ada Nabi kita

Teranglah alam semuanya

Hasan dan Husin anak Ali

Mati berperang Sabilillah

Semenjak lama ditinggal Nabi

Banyak agama nan berubah
Umpama bintang cahayanya

Cahaya anak bidadari

Semalam ada Nabi kita

Padamlah api raja Parsi

Baroba burung belibis

Terbangnya berdua-dua

Ruda kami sudahlah habis

Tampunglah doa bersama-sama

Kreativitas budaya Melayu yang Islami telah merebak kepada semua penjuru dunia Melayu. Dalam penampilan itu dikuakkan bahwa aktualisasi lahir tak dapat dipisahkan dan penampilan batin. Begitu pula penampilan dunia akan memberi akibat kepada nasib di akhirat. Jika dunia dan akhirat tak bisa seimbang, maka janganlah sampai lebih berat dunia daripada akhirat. Lebih balk berat kepada akhirat, sebab akhirat itu Lebih baik dan lebih utama dan dunia. Sebagaimana ruhani lebih utama dad jasmani. Ruhani abadi dalam perjalanan hidup dan mati sementara jasad berakhir setelah ajal tiba. Hal mi 
mendapat tempat yang istimewa dalam puisi Melayu yang religius. Rangkaian puisi serupa ini pernah ditulis oleh ulama besar mufti kerajaan Inderagiri Tuan Gum Abdurrahman Siddik bin Muhammad Apip dengan judul Syair Ibarat Khabar Akhirat: Tetapi yang jauh lebih banyak dihafal ialah sejumlah pantun tarekat, kisah azab kubur dan ratap Siti Fatimah. Orangorang Melayu dan buaiannya telah didendangkan dengan suasana perjalanan batin yang akan dilaluinya; suatu perjalanan yang amat penuh misteri setelah jasad ditinggalkan nyawa.

Jatuh indah yang pinang tinggi

Jatuh melayang selaranya

Penat sembahyang petang dan pagi

Tidak beriman payah saja

Rotan seni dibelah empat

Pucuk menjulai ke seberang

Tuhan dicari takkan dapat

Tuhan berlindung di tengah terang
Terbang pipit dari jagung

Singgah menghisap bunga pandan

Angin bertiup ombak bersabung

Nyawa kan pergi dad badan

Anak buaya di dalam padi

Tanam pitula di dalam kebun

Sewaktu muda segan mengaji

Kinilah tua inatalah lab rabun

Hampir tak ada upacara tradisional Melayu di Riau yang tidak menampilkan budaya dengan nafas Islam. Di daerah ini dibacakan berbagai upah-upah dalam upacara soslo-religius. Di sebelahnya lagi dibacakan bakoba. Bermacam nazam dapat dijumpai di daerah ini. Sementara di belahan pesisir Riau pembacaan berbagai syair pernah menjadi pelipur lara sehari-hari. Di Rantau ini orang Melayu membacakan Kayat Perang, semacam versi hikayat Hasan dan Husin atau Hikayat Muhammad Au Hanafiah. Tetapi bagi menutup upacara kematian yang ke 1000 hari sening dibacakan Hikayat Puteri Tujuh Sedangkan bagi ibu bapa yang kematian anaknya sering dihibur dengan Hikayat anak-anak.

Begitulah kebudayaan Melayu dan Islam, Kebudayaan ini telah pernah begitu subur, rimbun dan tinggi menjulang dalarn belantara kehidupan Melayu. Ajaran Islam yang kemudian dicairkan lagi dalam penampilan budaya telah memberi bekas kepada pribadi Melayu. Sifat malu menjadi satu diantara penampilan Melayu yang dipelihara, bagi tanda budi pekerti yang tinggi. Di sebelahnya dilestarikan pula sikap tidak suka menonjolkan diri. Kedua penampilan ini sering disalahtafsirkan oleh puak non-Melayu, sehingga nilai Islam yang larut dalam budaya Melayu itu, kemudian telah disalahgunakan untuk merugikan puak Melayu. Padahal malu dalam pandangan Melayu adalah suatu sifat yang dapat menjadi teknik untuk membatasi diri agar tidak melampaui norma-norma yang berlaku positif. Sedangkan sandingannya lagi tidak suka menonjolkan din, adalah teknik untuk menekan kesombongan. Sebab, dalam pandangan orang Melayu seperti pernah ditegaskan oleh salah satu tonggak agung pembina 
budayanya dikawasan ini orang yang besar itu ialah orang yang menjaga budi pekertinya

Bagaimana juga semangat kebudayaan dewasa ini bergelimang dengan ambisi, serakah dan kebendaan, tetapi bagi sebagian besar orang Meiayu yang teguh kepada tata nilainya yang telah dipadu oleh Islam, sulit baginya untuk ikut dalam bermain gelombang yang hanya berpijak kepada sikap curang, lancung dan tidak mengingat hidup yang akan mati. Bagaimanapun juga orang lain sukses mendapat kekayaan bendawi dengan memakai segala cara (yang penting kaya dan punya kedudukan) tanpa melalui usaha yang jujur serta mengikuti nilainilai luhur, namun orang Melayu yang teguh itu tidak akan goyah. Dalam keadaan ekstnim dia mungkin akan hijrah dan keadaan serupa itu dengan ucapan "biar aku jadi Sakai dan Kedayan". Ucapan yang terakhir ini memberi matlamat, betapa dirinya bersedia mengasingkan din, namun akan bersubahat dengan nilai-nilai yang curang dan busuk tetap tak mungkin dia lakukan. Inilah azam daripada orang Melayu yang telah menyadani bahwa matinya lebih utama dan hidupnya.

Bagaimana tidak akan demikian, sebab dalam pandangan Melayu yang Islami, harta benda itu yang utama ialah berkahnya, bukan jumlahnya. Harta yang banyak tetapi diperoleh dengan cara yang haram, curang atau licik dipandang tidak akan memberikan ketentraman. Malah akan mengundang celaka dan memabahaya. Jika tidak semasa hidup di dunia, akan ada balasan azab di akhirat di depan Kadi Malikul Adi. Sebaliknya harta yang berkah, yang dicari dengan tulang sendiri dalam norma-norma yang sesuai dengan panduan Islam, diyakini akan memberikan ketenangan dan suasana batin yang damai. Kalaulah tidak untuk dunia yang fana ini tetap akan diperoleh sebagai ganjaran amal saleh dan Allah Swt.

Ungkapan tidak tahu waktu dalam dunia Melayu bukanlah pertamatama ditujukan kepada orang yang tidak memakai waktunya untuk mencari nafkah dan harta benda dunia, tetapi diarahkan kepada orang Melayu yang tidak mempergunakan waktunya untuk sembahyang dan beramal. Sebab, jika dia sembahyang, niscaya orang itu mengenal waktu, sebab tiap sembahyang mempunyai rentangan waktunya masing-masing. Berbeda dengan orang hanya sibuk dengan harta dunia. Katanya dia mempergunakan dan tahu waktu. Padahal sebenarnya mereka sampai tidak mengenal waktu, karena asik dan sibuk mengejar kepingan benda dan tempat kedudukan. Seluruh jalan hidupnya lebur dalam aliran nafsu dan bendawi.

Dengan demikian, penampilan kebudayaan Melayu di Riau sebagai salah satu aktualisasi kebudayaan Islam, telah menjadi suatu kekayaan budaya dalam warna-warni kebhinnekaan budaya di Nusantara. Alur budaya ini telah meletakkan kebudayaan sebagai suatu cara mengabdi kepada Sang Khalik. Kebudayaan telah dipandang sebagam amanah Allah. Sebab kebudayaan tanpa Nur Ilahi tidaklah dapat membuat manusia lebih mulia dari binatang. Manusia malah jatuh kedalam kehinaan, sebagaimana telah diper- 
lihatkan oleh kebudayaan non-Islam yang hanya bersifat hedonis, materialistis dan pragmatis serta memuja makhluk semata. Manusia jadi mulia rupanya bukanlah oleh budayanya, tetapi oleh tauhidnya.

Sepintas lalu penampilan budaya Melayu yang Islami akan dikesan lamban dan tidak progresif. Tetapi agaknya ini perlu direnungkan. Kebudayaan Melayu dengan sistemnya yang demikian, tidak semata-mata menghandalkan potensi budaya manusia yang menganut bebas nilai. Kebudayaan ini berpijak dengan kokoh kepada ajaran Islam yang kebenarannya meliputi jagat raya. Geraknya bukanlah semata oleh ambisi hawa nafsu, tetapi karena kerinduan untuk mendapat keridhaan Tuhan.

Kebudayaan yang hedonis,materialialistis dan pragmatis (mementingkan nafsu, kekuasaan dan kebendaan) meskipun sepintas lalu dengan cepat memberikan "kebahagiaan "tetapi tiada mempunyai semangat batin dan jauh dan sinar kebenaran. Perjalanan budaya serupa itu hanyalah suatu perjalanan panjang tanpa arah, akhirnya kandas dalam tujuan hidup yang sia-sia. Sebaliknya kebudayaan Melayu dengan citra Islamnya, tampil dengan kesederhanaan dalam perimbangan jiwa dan raga. Mereka menikmati dunia sekedarnya, sehingga tidak sampai mabuk. Hidupnya tidak hanya sekedar mencari dan mengumpulkan benda-benda dengan nafsu dan kekuasaan yang rakus, tetapi setelah mendapatkan sekedar yang diperlukan, hidup mi ditingkatkan lagi kepada mencari makna. Dan makna hidup hanya akan bersua dalam pandangan Melayu, dengan jalan mengerjakan yang disuruh (oleh agama Islam) dan menghentikan yang ditegahnya. Pada tingkat lahir hidupnya berusaha mempunyai jasa, sebab hidup yang tidak berjasa bagaikan hutang yang tidak lansai. Pada tingkat batin (yang lebih tinggi) diperoleh martabat din yang mulia. Dan hanya din yang mulia yang bisa berhadapan dengan Khaliknya untuk memperoleh anugerah yang tiada tara.

\section{KESIMPULAN}

Enkulturisasi kebudayaan Melayu, adalah mengimplementasikan nilai Islam dalam setiap gerak kehidupan. Adanya setiap aktifitas yang dilakukan harus mencerminkan dan dilandasi oleh semangat "amar ma'ruf nahi munkar". Dalam konteks ini Islam merupakan pedoman yang harus dipatuhi dalam setiap tindakan yang dilakukan. Enkulturisasi nilai nilai Islam dalam masyarakat Melayu-Riau terjadi karena faktor fleksibelitas kebudayaan dan kepribadian orang Melayu.

Enkulturisasi Islam dan kebudayaan Melayu agar supaya manusia belajar dan menggunakan akal budinya untuk meningkatkan peradaban Melayu yang mempunyai nilai nilai yang tinggi,adaptif dan universal. Banyak al-Qur'an maupun al-sunnah yang mendorong manusia, bahkan terdapat ayat-ayat yang memperlihatkan semangat intelektualisme,rasionalisme ,substansial dan universal misalnya ayat-ayat yang menggunakan kata-kata 
"afalâ ta'qilûn, afalâ tafhamûn, dan afalâ ta'tafakkarûn", yang kesemuanya mengandung makna menggunakan akal pikiran untuk kemajuan peradaban Melayu yang semulanya adalah animisme, hindu-budha berenkulturisasi terhadap nilai-nilai Islam.

\section{DAFTAR PUSTAKA}

Anomin, 2002 Strategi Penegembangan Kota Riau. Riau, Humas.

Anomin, 2002 Himpunan Peraturan Daerah Kota Riau, Riau, Bagian Hukum Sekretariat Daerah Kota Riau.

Anomin, 2002 ,Riau Dalam Angka 2002, Riau, Statistik.

Anomin,2002, Kondisi Sosial Budaya Kota Riau, Riau, Beppeko.

Abu Hassan Othman, 1971. "Proses Sosialisasi Individu dalam Masyarakat Melayu Kampung Selemak, Negeri Sembilan". Tesis Sarjana Sastera, Jabatan Pengajian Melayu, Universiti Malaya, Kuala Lumpur.

Azizah Kassim, 1969. "Kedudukan Wanita di dalam Masyarakat Melayu Beradat Perpatih di Negeri Sembilan". Tesis Sarjana Sastera, Jabatan Pengajian Melayu, Universiti Malaya, Kuala Lumpur.

Banks, D., 1983. Malay Kinship. Institute for the Study of Human Issues, Philadelphia.

Barnouw, V., 1975. Ethnology: An Introduction to Anthropology, Jilid II, The Dorsey Press.

Burges, E.W,Locke, H.J. dan Thomes, M.M,1971. The Family: From Traditional to Companions/up. (Edisi Keempat). Von Nostrand Reinhold Company.

Djamour, J, 1965. Malay Kinship and Marriage in Singapore. London School of Economics Monographs on Social Anthropology, No.21. University of London: The Athlone Press.

Edi Ruslan 200 ,Pe Amanriza, Senarai Upacara Adat Perkawinan Melayu Riau, Pekanbaru, Unri Press.

Firth, R. 1966. Malay Fishermen, Their Peasant Economy. (Edisi Kedua). London: Routledge \& Kegan Paul Ltd.

,1966. Housekeeping among Malay Peasants. London School of Economics Monographs on Social Anthropology, No. 7, University of London: The Athlone Press.

Fox, R, 1971. Kinship and Marriage: An Anthropological Perspective. Penguin Books.

Goode, W.J., 1963. World Revolution and Family Patterns. London: Collier Macmillan Ltd.

Hamidi,U.U, 1999 . Islam dan Masyarakat Melayu di Riau.Pekanbaru, UIR Press.

Herdi,S 2003 Kota Dumai : Mutiara Pantai Timur Sumatera, Pekanbaru, Unri Press. 
Husni Thamrin,2003 Sakai : Kekuasaan, Pembangunan dan Marjinalisasi, Pekanbaru, Gagasan Pers UIN Suska Riau.

------------,2007 Etnografi Melayu : Tradisi dan Modernisasi,Suska Press Pekanbaru

---------2007, Fenomena Budaya Sosial Agama dan Pendidikan,Pekanbaru LPP UIN

Goody, J [ed], 1971. Kinship, A Selected Readings. (Edisi Pertama). Penguin Books.

Keesing, R, 1975. Kin Group and Social Structure. Holt, Reinhart and Winston, Inc.

Kenkell, W.F, 1973. The Family in Perspective. (Edisi Ketiga). Meredith Corporation.

Kuchiba, M, Tsubouchi, Y., dan Maeda, M., ig7g. Three Malay Villages: A Sociology of Padi Growers in West Malaysia. Monographs of the Center for Southeast Asian Studies, Kyoto University, Honolulu: The University of Hawaii Press.

Md. Ali Alhamidy, 198!. Islam dan Perkahwinan. Singapura: Alharamain Pte. Ltd.

Nordin Selat, 1976. Sistem Sosial Adat Perpatih. Utusan Melayu Berhad.

Ogburn, W.F., dan Nimkoff M.F. 1955. Technology and the Changing Family. Houghton Mifflin Company.

Tham Seong Chee, 1979. "Social Change and the Malay Family", dalam Kuo, E.C.Y., dan Wong, A.K., The Contemporary Family in Singapore. Singapore University Press.

Soewardi,(ed) 1977 Sejarah Riau, Pekanbaru, Pemda

Tennas Efendi, 1998 Tunjuk Ajar Melayu, Pekanbaru

Winch, R, 1963. The Modern Family. (Edisi Ketiga). Holt, Reinhart and Winston, Inc.

Zaid H. Aihamidy, ig8i. Rumah Tangga Muslim. Semarang, Republik Indonesia: Penerbit Mujahidin.

Zainal Kling, 1977. "Bentuk dan Organisasi Keluarga di Kampung Melayu". dalam Zainal Kling [ed]. Masyarakat Melayu antara Tradisi dan Perubahan. Utusan Publications \& Distributers. 


\section{PETUNJUK PENULISAN ARTIKEL}

Redaksi menerima tulisan ilmiah untuk dimuat pada Al-Fikra dengan catatan:

1. Artikel merupakan hasil penelitian dan kajian tentang studi keislaman.

2. Artikel merupakan produk ilmiah orisinil, belum pernah dipublikasikan di media manapun.

3. Artikel ditulis dalam bahasa Indonesia baku (atau bahasa asing) dengan ragam tulisan ilmiah, bukan ilmiah popular.

4. Naskah tulisan berkisar antara 15 sampai 40 halaman.

5. Artikel diketik satu spasi pada kertas A4.

6. Artikel diserahkan ke secretariat pengelola jurnal Al-Fikra dalam bentuk print out/hard copy dan soft copy dengan menyertakan CD atau via email ke: Redaksialfikra@yahoo.com / pps_uinsuskariau@yahoo.com

7. Setiap artikel disertai abstrak yang memaparkan secara singkat dan jelas keseluruhan isi tulisan.

8. Abstrak ditulis dalam bahasa Inggris.

9. Tulisan disertai dengan keywords (kata kunci).

10. Artikel disertai dengan footnote dan dilengkapi dengan bibliografi (daftar kepustakaan).

a. Format penulisan dalam buku rujukan dalam footnote adalah: Pengarang, Judul, (Kota Tempat Terbit: Penerbit, Tahun Terbit), hlm. Contoh Hasan Hanafi, Islam in the Modern Word: Religion, Ideology and Develovment (Kairo: Anglo Egyptian Bookshop, 1995), Vol. 1, hlm. 408.

b. Pengulangan reverensi yang belum diselingi referensi lain digunakan Ibid (untuk artikel berbahasa Indonesia dan Inggris) atau تفس المر اجع (untuk artikel berbahasa Arab). 
c. Pengulangan referensi yang sudah diselingi referensi lain tidak menggunakan op.cit atau loc.cit, tetapi ditulis dengan cara: satu kata dari nama penulis, 1-3 kata dari judul, hlm. Contoh Hasan, Islam in The Modern, hlm. 120.

d. Penulisan Bibliografi(untuk artikel berbahasa Indonesia), Bibliographi (untuk artikel berbahasa Inggris) dan الهصادر(untuk artikel berbahasa Arab), ditulis dengan cetak tebal (bold).

e. Contoh penulisan: MAdjid, Nurchalis, Islam Doktrin dan Peradaban, (Jakarta: Yayasan Wakaf Paramadina, 2000).

f. Diurutkan sesuai dengan urutan alphabet (sort).

\section{PEDOMAN TRANSLITERASI ARAB-INDONESIA}

Merujuk pada SKB Menteri Agama dan Menteri Pendidikan dan Kebudayaan $\mathrm{Ri}$, tertanggal 22 Januari 1988 No. 158/1987 dan 0543b/U/1987

I. Konsonan Tunggal

\begin{tabular}{|c|c|c|c|}
\hline Huruf Arab & Nama & Huruf Latin & Keterangan \\
\hline 1 & Alif & & tidak dilambangkan \\
\hline ب ب & Bā' & b & be \\
\hline 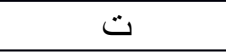 & Tâ' & $\mathrm{t}$ & te \\
\hline ث & Śā' & $\mathrm{s}$ & es titik di atas \\
\hline ج & $\mathrm{Jim}$ & j & je \\
\hline$\tau$ & Hā' & $\mathrm{h}$ & ha titik di bawah \\
\hline$\dot{\tau}$ & Khā' & $\mathrm{kh}$ & ka dan ha \\
\hline د & Dal & $\mathrm{d}$ & de \\
\hline ذ & Żal & $\dot{z}$ & zet titik atas \\
\hline J & Rā' & $r$ & er \\
\hline j & Zai & $\mathrm{z}$ & zet \\
\hline 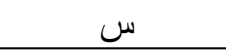 & $\sin$ & $\mathrm{s}$ & es \\
\hline ش ش & Syīn & sy & es dan ye \\
\hline ص ص & Şād & $\mathrm{s}$ & es titik di bawah \\
\hline 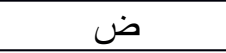 & Dād & $\mathrm{d}$ & de titik di bawah \\
\hline$b$ & Tà' & $\mathrm{t}$ & te titik di bawah \\
\hline b & Zā' & $z$ & zet titik di bawah \\
\hline$\varepsilon$ & 'Ayn & $\ldots \cdot \ldots$ & $\begin{array}{lll}\text { koma } & \text { terbalik } \\
\text { atas) } & & \end{array}$ \\
\hline$\dot{\varepsilon}$ & Gayn & g & ge \\
\hline
\end{tabular}




\begin{tabular}{|c|c|c|c|}
\hline ف ف & Fā' & $f$ & ef \\
\hline ق & Qāf & $q$ & qi \\
\hline ك & Kāf & $\mathrm{k}$ & ka \\
\hline J & Lām & I & el \\
\hline 5 & Mīm & $\mathrm{m}$ & em \\
\hline ن & Nūn & $\mathrm{n}$ & en \\
\hline 9 & Wau & w & we \\
\hline . & Hāó & $\mathrm{h}$ & ha \\
\hline 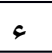 & Hamzah & $\therefore$ & apostrof \\
\hline ي & Yā' & $y$ & ye \\
\hline
\end{tabular}

II. Konsonan rangkap karena tasydid di tulis rangkap:

مثعقد ينditulis muta'aqqadidin

عدة ditulis 'iddah

III. Tâ marbutah di akhir kata

1. Bila dimatikan, ditulis $\mathrm{h}$ :

هبةditulis hibah

جditulis Jizyah

(ketentuan ini tidak diperlukan terhadap kata-kata Arab yang sudah terserap kedalam bahasa indonesia, seperti salat, zakat, dan sebagainya, kecuali dikehendaki lafal asli).

2. Bila dihidupkan karena berangkai dengan kata lain, ditulis t:

نعمة الله

كاة الفطر jolitulis zakatul-fitri

IV. Vokal pendek

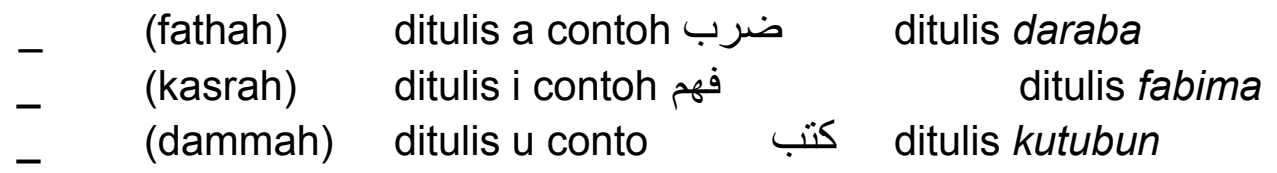

V. Vokal panjang

1. Fathah + alif, ditulis â (garis di atas)

جاهلية ditulis jahiliyyah

2. Fathah + alif maqsur ditulis â (garis atas)

يسeditulis yas'â

3. Kasrah + ya mati, ditulis ì (garis di atas) 
مجditulis majid

4. Dammah + wau mati, ditulis ū (dengan garis di atas) ضgditulis furud

VI. Vokal rangkap

1. Fathah + ya mati, ditulis ay S.ينditulis baynakum

2. Fathah + wau mati, ditulis au Jölitulis qawl

VII. Vokal-vokal pendek yang berurutan dalam satu kata, dipisahkan dengan Apostrof

انتمditulis a’antum

اعدت ditulis u'iddat

délditulis la'in syakartum

VIII. Kata sandang Alif + Lam

1. Bila didukung dengan qamariyah ditulis alالقران ditulis al-Qur'ân القياس ditulis al- Qiyâs

2. Bila diikuti huruf syamsiah, ditulis dengan menggandeng huruf syamsiyah yang mengikuti yang mengikutinya serta menghilangkan huruf 1-nya

السماءditulis as-sama'

الثمس ditulis asy-syams

IX. Huruf besar

Huruf besar dalam tulisan latin digunakan sesuai dengan ejaan yang diperbaharui (EYD)

X. Penulisan kata-kata dalam rangkaian kalimat dapat ditulis menurut bunyi atau pengucapannya dan penulisannya

ذذوي الفروض

اهل السنة ditulis ahlussunnah atau ahl as-sunnah 